Article

\title{
Antiproliferative Activity and Antioxidant Potential of Extracts of Garcinia gardneriana
}

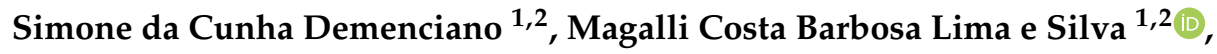 \\ Caroline Almeida Farias Alexandrino ${ }^{1}$, Wilson Hino Kato Junior ${ }^{3}$, \\ Patrícia de Oliveira Figueiredo ${ }^{3}{ }^{\circ}$, Walmir Silva Garcez ${ }^{2,3}$, Raquel Pires Campos ${ }^{3}$, \\ Rita de Cássia Avellaneda Guimarães ${ }^{2, *}$, Ulana Chaves Sarmento ${ }^{4}$ and Danielle Bogo ${ }^{1,2}$ \\ 1 Molecular Biology and Cell Culture Laboratory, School of Pharmaceutical Sciences, Foods and \\ Nutrition (Facfan), Federal University of Mato Grosso do Sul (UFMS), Cidade Universitária, \\ Campo Grande 79070-900, Brazil; sinutri_2@hotmail.com (S.d.C.D.); magallicbls@gmail.com (M.C.B.L.eS.); \\ carolfalexandrino@gmail.com (C.A.F.A.); danielle.bogo@ufms.br (D.B.) \\ 2 Graduate Program in Health and Development in the Central-West Region of Brazil, Federal University of \\ Mato Grosso do Sul, Campo Grande 79079-900, Brazil; walmirgarcez@gmail.com \\ 3 Laboratory PRONABio (Laboratory of Bioactive Natural Products)—Chemistry Institute, Federal University \\ of Mato Grosso do Sul, Cidade Universitária, Campo Grande 79070-900, Brazil; \\ hinokato@gmail.com (W.H.K.J.); patricia.figueiredo@ufms.br (P.d.O.F.); raquel.campos@ufms.br (R.P.C.) \\ 4 Laboratory of Physical Chemistry of Foods, School of Pharmaceutical Sciences, Foods, Federal University of \\ Mato Grosso do Sul (UFMS), Cidade Universitária, Campo Grande 79070-900, Brazil; \\ ulanachaves@hotmail.com \\ * Correspondence: rita.guimaraes@ufms.br; Tel.: +55-67-3345-7416
}

Received: 10 April 2020; Accepted: 10 May 2020; Published: 14 July 2020

check for updates

\begin{abstract}
The aim of this study was to evaluate the antiproliferative activity, the antioxidant potential, and the chemical profile obtained from the whole fruit and from leaves of Garcinia gardneriana, a fruit tree from Brazilian Cerrado. To determine in vitro antiproliferative activity, the following neoplastic cell lines were considered, along with an immortalized nontumor cell line. The antioxidant potential was determined, and the evaluation of antiradical air activity was performed. The levels of vitamin $C$ and carotenoids were determined. The chemical profile was analyzed by high-performance liquid chromatography coupled to a diode array detector and a mass spectrometer using electrospray ionization interface. The chloroform fraction of the leaf showed antioxidant activity. The vitamin $\mathrm{C}$ content had lower values in fruits and higher in leaves. The content of carotenoids for fruits and leaves was expressive. The ethanolic extract and the hexane and chloroform fractions of fruits were active in all neoplastic lines tested. The leaves showed cytotoxic activity in the hexane fraction in the breast carcinoma line. The analysis of data obtained verified the presence of dimers, monomers, and tetramers of hexoses, polycarboxylic acids, xanthones, flavonoids, biflavonoids, and benzophenones.
\end{abstract}

Keywords: bacupari; anticancer; HPLC-DAD-MS; brazilian cerrado fruits; cytotoxicity

\section{Introduction}

The Brazilian Cerrado is the second largest biome in Brazil, occupying 24\% of the national territory. The vegetation of this biome is characterized by a diversity of native fruits with peculiar sensory characteristics and high nutritional and economic potential. Fruit consumption has grown in the national and international markets as a result of access to health information [1].

Known as a natural source of bioactive compounds, there is great interest in preserving and valuing local biodiversity to encourage consumption and use of Brazilian Cerrado's fruits. They adapt 
to the soils of the region with low implementation costs and show great species richness, which allows them to be classified as "plants of the future" [2].

Phytochemical studies have revealed the presence of several bioactive secondary metabolites for the species and genus Garcinia, such as phenolic compounds, mainly xanthones [3-7], and benzophenones and bioflavonoids [8-11]. Among these species is Garcinia gardneriana (Planchon \& Triana) Zappi, popularly known as bacupari, which has been used in folk medicine to treat inflammation, pain, urinary infections, and other infections. Garcinia brasiliensis shows important antimicrobial and antioxidant properties in leaves, making its use a potential for the development of new drugs to treat cutaneous lesions [12].

Phenolic substances are efficient natural antioxidants, avoiding oxidative stress. The oxidative process may be the etiology of several chronic noncommunicable diseases, such as atherosclerosis, diabetes, obesity, neurodegenerative disorders, and cancer [13]. Cases involving high levels of oxidative stress or DNA damage have been reported in human malignancies [14].

Cancer is one of the chronic diseases with the highest mortality rate in the world. Its origin is fundamentally genetic and developed by the accumulation of mutations in cellular DNA. Physical and chemical mutagenic agents in the environment or toxic products of the cell itself, such as free radicals, can also contribute to its development. Thus, substances with an antioxidant activity act against oxidative stress, preventing such diseases [15].

In addition, there are studies on the anticancer activity of plants belonging to the genus Garcinia, such as the case of Garcinia dulcis fruit methanolic extract, which has anticancer activity in the liver cancer cell line (HepG2) [16,17].

The isolation of compounds is essential for the development of new substances with antiproliferative and antioxidant activities [18]. Thus, considering Garcinia species was proven to be a rich source of active metabolites, including reports of antioxidant and anticancer activities, this study determines the chemical composition of G. gardneriana fruits and leaves and evaluates the antiproliferative activity against a panel of cancer cell lines and the free radical scavenging activity of the respective extracts and fractions in order to clarify whether this plant is a potential source of prototypes to drugs with anticancer activity.

\section{Results}

\subsection{Identification of the Constituents by HPLC-DAD (Diode Array Detector)-MS}

The determination of the chemical profiles of FEE (fruit ethanolic extract), EEFH (hexane fraction), EEFC (chloroform fraction), EEFA (ethyl acetate fraction), EEFW (hydromethanolic fraction), EEL (ethanol leaf extract), EELH (hexane fraction), EELC (chloroform fraction), EELA (ethyl acetate fraction), and EELW (hydromethanolic fraction) were performed based on UV, MS, and MS/MS data as compared with data described in the literature [11-25]. Twenty-six compounds were tentatively identified (Tables 1 and 2, Figure 1). They are monomers, dimers, and tetramers of hexoses (1, 2, and 9), polycarboxylic acids (3-5), xanthones $(\mathbf{1 5}, \mathbf{1 1}, \mathbf{1 9}$, and 22), flavonoids (11-14), biflavonoids (6-8, 10, 16-18, 20, 21, and 23), and benzophenones (24 and 25) (Figure 1). 


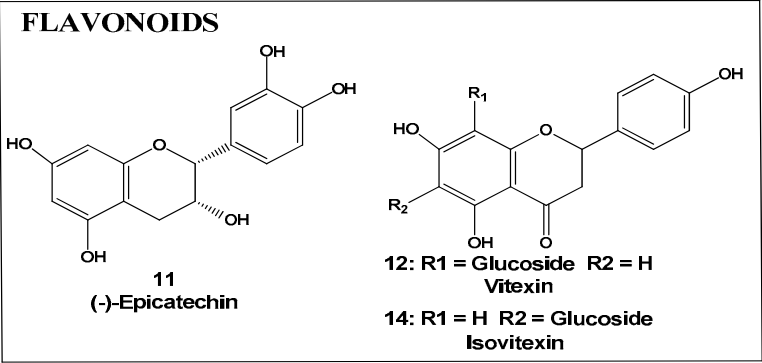

BIFLAVONOIDS
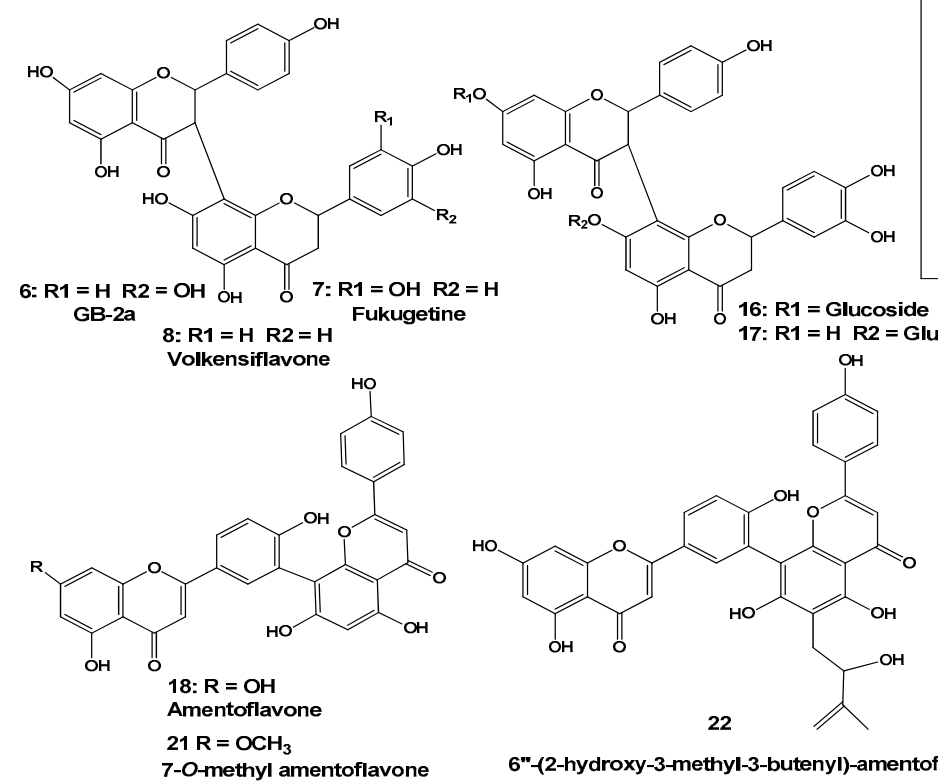

6"-(2-hydroxy-3-methyl-3-butenyl)-amentoflavone
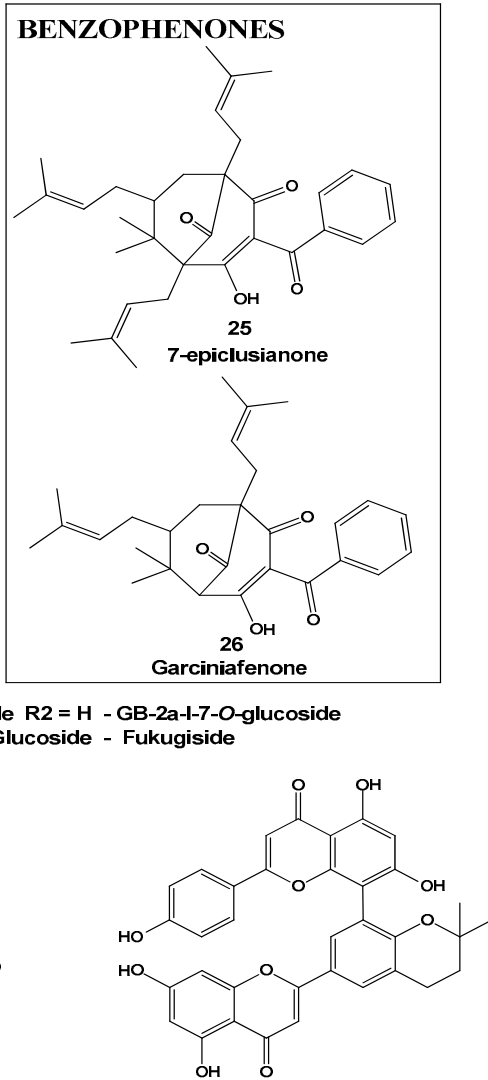

Garciniaflavone D

Figure 1. Compounds identified in the ethanol extracts of fruits (EEF) and leaves (EEL) of Garcinia gardneriana.

The HPLC-DAD-MS analysis of EEF (ethanol fruits' extract) and fractions resulted in the identification of the compounds listed in Table 1.

Table 1. Compounds tentatively identified from the ethanol extract of Garcinia gardneriana fruits (EEF).

\begin{tabular}{ccccccc}
\hline Substance & Rt (min) & Compound & $\begin{array}{c}{[\mathbf{M}-\mathbf{H}]^{-}} \\
\mathbf{( M F )}\end{array}$ & $\begin{array}{c}\text { Precursor ion } \\
(\mathbf{m} / \mathbf{z})\end{array}$ & $\begin{array}{c}\text { Fragment Ions } \\
(\mathbf{m} / \mathbf{z})\end{array}$ & UV \\
\hline $\mathbf{1}$ & 1.1 & Dimers of hexoses & $\mathrm{C}_{12} \mathrm{H}_{21} \mathrm{O}_{11}$ & 341.1097 & & \\
$\mathbf{2}$ & 1.1 & Monomers of hexoses & $\mathrm{C}_{6} \mathrm{H}_{11} \mathrm{O}_{6}$ & 179.0551 & & \\
$\mathbf{3}$ & 1.2 & Hydroxycitric acid lactone & $\mathrm{C}_{6} \mathrm{H}_{5} \mathrm{O}_{7}$ & 189.0034 & & \\
$\mathbf{4}$ & 1.3 & Glycosylated citric acid & $\mathrm{C}_{12} \mathrm{H}_{17} \mathrm{O}_{12}$ & 353.0725 & & \\
$\mathbf{5}$ & 1.4 & Citric acid & $\mathrm{C}_{6} \mathrm{H}_{7} \mathrm{O}_{7}$ & 191.0191 & & 280 \\
$\mathbf{6}$ & 29.4 & GB-2a biflavonoid & $\mathrm{C}_{30} \mathrm{H}_{21} \mathrm{O}_{11}$ & 557.1105 & & \\
$\mathbf{7}$ & 30.0 & Fukugetine & $\mathrm{C}_{30} \mathrm{H}_{19} \mathrm{O}_{11}$ & 555.0935 & $429,403,401,295$ & 280 \\
$\mathbf{8}$ & 31.3 & Volkensiflavone & $\mathrm{C}_{30} \mathrm{H}_{19} \mathrm{O}_{10}$ & 539.0982 & 413,387 & 280 \\
\hline
\end{tabular}

Note: MF, molecular formula; RT, retention time; UV, ultraviolet. All MFs were determined from the accurate mass considering a mass error and mSigma lower than 8 ppm and 30, respectively.

Among the compounds identified, the presence of citric acid lactone (3) stands out. Biflavonoids GB-2a (6), fukugetine (7), and volkensiflavone (8) were also identified.

The compounds identified in the ethanolic extract EEF were also observed in the analyzed phases EEFC, EEFA, and EEFW at different proportions (Figure 2), except for the EEFW, in which biflavonoids (6-8) were not observed. The EEFC fraction concentrated biflavonoids (6 and 8) and xanthone (15), while the EEFA fraction concentrated biflavonoid (6) (Figure 2). 


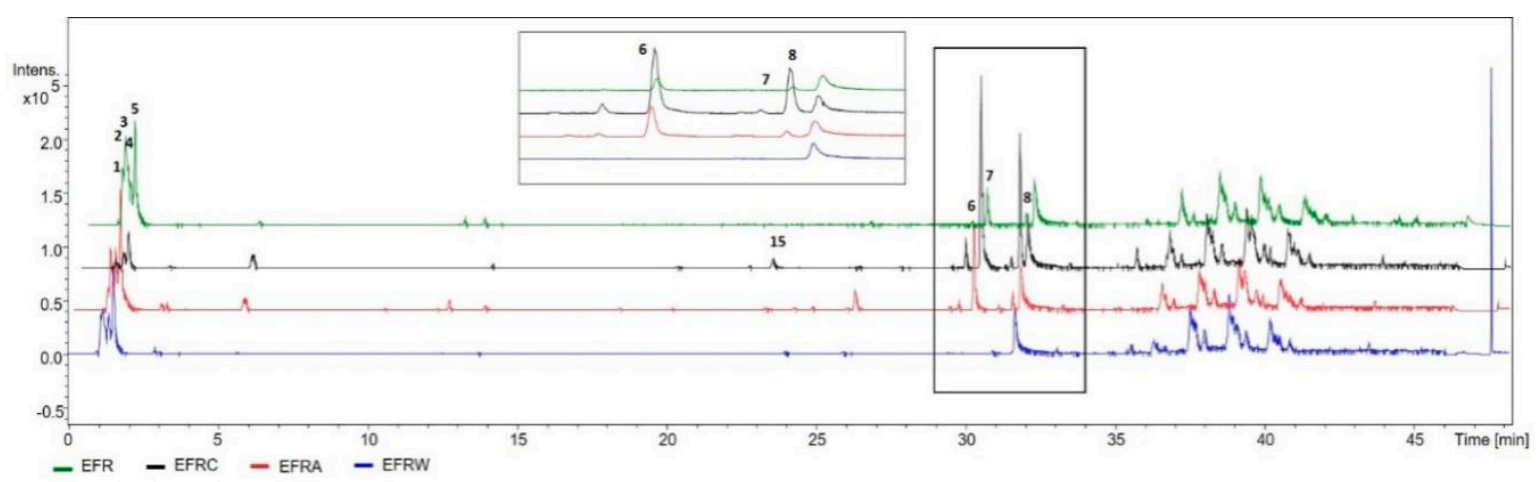

Figure 2. Base peak chromatogram (BPC) obtained by HPLC-DAD-MS of EEF extract and the fractions EEFC (chloroform fraction), EEFA EEFA (ethyl acetate fraction), and EEFW (hydromethanolic fraction). The identification of chromatographic peaks is described in Table 1 and all the chromatograms are in the same intensity range.

The HPLC-DAD-MS analysis of EEL (leaf extract) resulted in the identification of the compounds listed in Table 2.

Table 2. Compounds tentatively identified from the ethanol extract of Garcinia gardneriana leaves (EEL).

\begin{tabular}{|c|c|c|c|c|c|c|}
\hline Substance & Rt (min) & Compound & $\begin{array}{c}{[\mathrm{M}-\mathrm{H}]^{-}} \\
(\mathrm{MF})\end{array}$ & $\begin{array}{l}\text { Precursor Ion } \\
(\mathrm{m} / \mathrm{z})\end{array}$ & Fragment Ions $(m / z)$ & UV \\
\hline 1 & 1.2 & Dimers of hexoses & $\mathrm{C}_{12} \mathrm{H}_{21} \mathrm{O}_{11}$ & 341.1097 & & \\
\hline 2 & 1.2 & Monomers of hexoses & $\mathrm{C}_{6} \mathrm{H}_{11} \mathrm{O}_{6}$ & 179.0551 & & \\
\hline 3 & 1.2 & Hydroxycitric acid lactone & $\mathrm{C}_{6} \mathrm{H}_{5} \mathrm{O}_{7}$ & 189.0052 & & \\
\hline 6 & 29.4 & GB-2a biflavonoid & $\mathrm{C}_{30} \mathrm{H}_{21} \mathrm{O}_{11}$ & 557.1105 & 431,295 & 280 \\
\hline 7 & 30.0 & Fukugetine & $\mathrm{C}_{30} \mathrm{H}_{19} \mathrm{O}_{11}$ & 555.0956 & $429,403,401,295$ & 280 \\
\hline 8 & 31.3 & Volkensiflavone & $\mathrm{C}_{30} \mathrm{H}_{19} \mathrm{O}_{10}$ & 539.0982 & 413,387 & 280 \\
\hline 9 & 1.2 & Tetramer of hexoses & $\mathrm{C}_{24} \mathrm{H}_{43} \mathrm{O}_{22}$ & 683.2259 & 341,179 & \\
\hline 10 & 12.1 & Procyanidin B & $\mathrm{C}_{30} \mathrm{H}_{25} \mathrm{O}_{12}$ & 577.1361 & 407,289 & 280 \\
\hline 11 & 12.5 & epicatechin & $\mathrm{C}_{15} \mathrm{H}_{13} \mathrm{O}_{6}$ & 289.0724 & & 280 \\
\hline 12 & 17.9 & Vitexin & $\mathrm{C}_{21} \mathrm{H}_{19} \mathrm{O}_{10}$ & 431.1000 & 311,283 & 273,330 \\
\hline 13 & 18.2 & Vitexin-O-rhamnoside & $\mathrm{C}_{27} \mathrm{H}_{29} \mathrm{O}_{14}$ & 577.1564 & 413,293 & 270,340 \\
\hline 14 & 18.6 & Isovitexin & $\mathrm{C}_{21} \mathrm{H}_{19} \mathrm{O}_{10}$ & 431.0996 & & 273,330 \\
\hline 15 & 23.0 & Tetrahydroxy-xanthone & $\mathrm{C}_{13} \mathrm{H}_{7} \mathrm{O}_{6}$ & 259.0251 & 215,187 & $275,315,360$ \\
\hline 16 & 24.0 & GB-2a-I-7-O-glucoside & $\mathrm{C}_{36} \mathrm{H}_{31} \mathrm{O}_{16}$ & 719.1597 & $431,313,295$ & 284 \\
\hline 17 & 24.5 & Fukugiside & $\mathrm{C}_{36} \mathrm{H}_{29} \mathrm{O}_{16}$ & 717.1501 & $565,493,429,403$ & 276,350 \\
\hline 18 & 32.0 & Amentoflavone & $\mathrm{C}_{30} \mathrm{H}_{17} \mathrm{O}_{10}$ & 537.0834 & $443,417,399,375,331$ & 269,336 \\
\hline 19 & 33.7 & Prenylated Xanthone & $\mathrm{C}_{18} \mathrm{H}_{15} \mathrm{O}_{6}$ & 32.0877 & $311,295,272$ & 275,316 \\
\hline 20 & 34.0 & Prenylated Xanthone & $\mathrm{C}_{18} \mathrm{H}_{15} \mathrm{O}_{6}$ & 327.0888 & $283,272,258,243$ & 275,320 \\
\hline 21 & 34.4 & 7-O-methylamentoflavone & $\mathrm{C}_{31} \mathrm{H}_{19} \mathrm{O}_{10}$ & 551.0995 & $457,431,413,389,345$ & 272,330 \\
\hline 22 & 34.5 & Amentoflavone & $\mathrm{C}_{35} \mathrm{H}_{25} \mathrm{O}_{11}$ & 621.1426 & $551,441,431,389,345$ & 276,328 \\
\hline 23 & 35.4 & Prenylated Xanthone & $\mathrm{C}_{18} \mathrm{H}_{15} \mathrm{O}_{8}$ & 311.0920 & $295283,267,255$ & 277,307 \\
\hline 24 & 36.2 & Garciniaflavone D & $\mathrm{C}_{35} \mathrm{H}_{25} \mathrm{O}_{10}$ & 605.1458 & $511,485,467,443,399,374,309,227$ & 275,333 \\
\hline 25 & 42.8 & 7-epiclusianone & $\mathrm{C}_{33} \mathrm{H}_{41} \mathrm{O}_{4}$ & 501.3007 & $417,347,305,175$ & 276,307 \\
\hline 26 & 43.1 & Garciniaphenone & $\mathrm{C}_{28} \mathrm{H}_{33} \mathrm{O}_{4}$ & 433.2390 & $349,295,279,241$ & 278,307 \\
\hline
\end{tabular}

Note: MF, molecular formula; RT, retention time; UV, ultraviolet. All MFs were determined from the accurate mass considering a mass error and mSigma lower than 8 ppm and 30, respectively.

In addition to hydroxycitric acid lactone (3), this extract showed xanthones $(\mathbf{1 5}, \mathbf{1 1}, \mathbf{1 9}$, and 22), flavonoids (11-14), biflavonoids (6-8, 10, 16-18, 20, 21, and 23), and benzophenones (24 and 25) (Table 2). Comparing the composition of the EEL extract and its fractions, the prenylatedxanthones15, 11, 19, and 22 and the biflavonoids 20, 21, and 23 were found only in the chloroform fraction EELC, while the flavonoids 11-14 were concentrated at the EELA ethyl acetate fraction. None of the analyzed fractions (EELC, EELA, and EELW) showed the benzophenones 24 and 25, implying that they were separated to the hexane fraction EELH (Figure 3). 


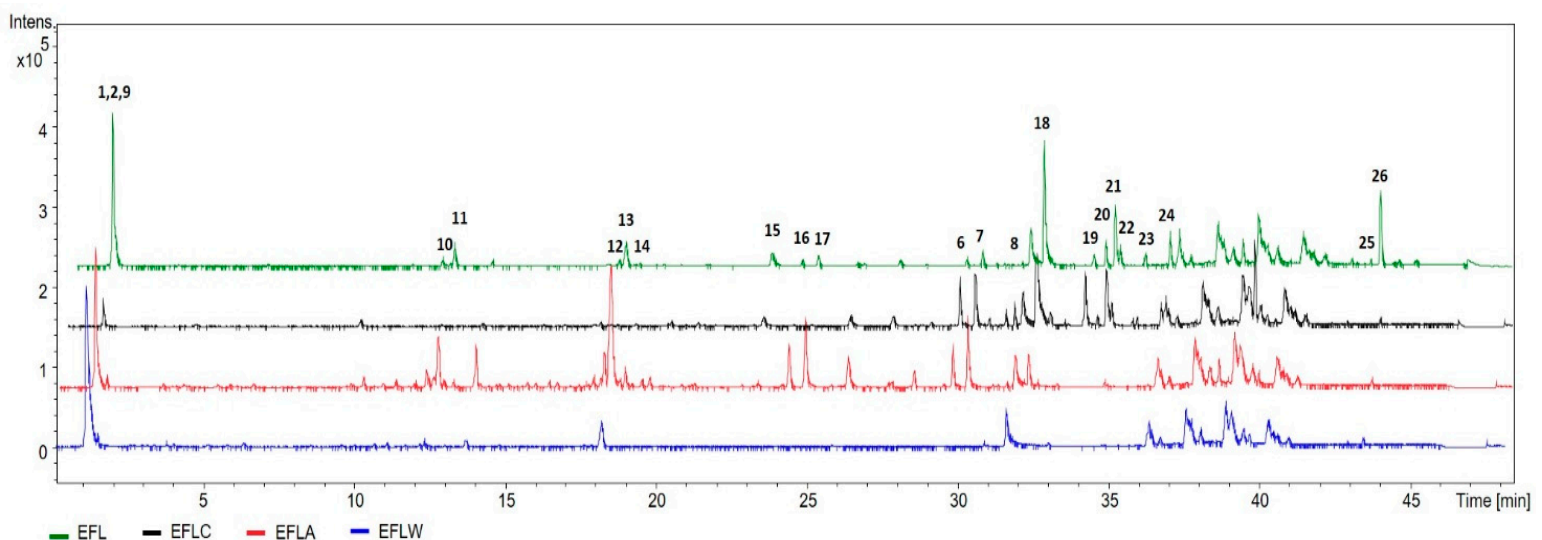

Figure 3. Base peak chromatogram (BPC) obtained by HPLC-DAD-MS of EEL extract and the fractions EELC (chloroform fraction), EELA (ethyl acetate fraction), and EELW (hydromethanolic fraction). The identification of chromatographic peaks is described in Table 2 and all the chromatograms are in the same intensity range.

\subsection{Centesimal Composition and Antioxidant Activity of Fruits and Leaves of Garcinia gardneriana}

Table 3 shows the moisture, ash, protein, lipid, and carbohydrate content of the species under study.

Table 3. Centesimal composition and bioactive compounds of fruits and leaves of Garcinia gardneriana.

\begin{tabular}{ccc}
\hline Parameter & $\begin{array}{c}\text { Fruit } \\
\text { Mean } \pm \text { MSE }\end{array}$ & $\begin{array}{c}\text { Leaf } \\
\text { Mean } \pm \text { MSE }\end{array}$ \\
\hline Moisture (\%) & $82.17 \pm 0.91^{\mathrm{a}}$ & $30.51 \pm 2.77^{\mathrm{b}}$ \\
Ash (\%) & $0.40 \pm 0.015^{\mathrm{a}}$ & $4.93 \pm 0.06^{\mathrm{b}}$ \\
Protein (\%) & $1.35 \pm 0.12^{\mathrm{a}}$ & $7.4 \pm 0.08^{\mathrm{b}}$ \\
Lipids (\%) & $5.41 \pm 0.1^{\mathrm{a}}$ & $2.11 \pm 0.09^{\mathrm{b}}$ \\
Carbohydrates (\%) ${ }^{* *}$ & $10.64 \pm 0.83^{\mathrm{a}}$ & $54.79 \pm 2.89^{\mathrm{b}}$ \\
Phenols (mg GAE 100 g $\left.\mathrm{g}^{-1}\right)$ & $107.07 \pm 9.65^{\mathrm{a}}$ & $132.46 \pm 2.32^{\mathrm{a}}$ \\
Vit C (mg 100 g $\left.{ }^{-1}\right)$ & $25.23 \pm 3.58^{\mathrm{a}}$ & $30.26 \pm 2.01^{\mathrm{a}}$ \\
Carotenoids (mg $\beta$-carotene $\left.100 \mathrm{~g}^{-1}\right)$ & $27.05 \pm 4.04^{\mathrm{a}}$ & $76.25 \pm 3.51^{\mathrm{b}}$ \\
\hline
\end{tabular}

Different letters on rows indicate significant difference by Tukey test $(p<0.01)$; MSE, mean standard error; mean value \pm standard deviation; $\mathrm{n}=3$. ${ }^{*}$ Calculations by difference. GAE: Gallic acid equivalent.

In leaves, a high percentage of ash, about 10 times higher than that found in fruits, indicates a high mineral content. The lipid content of fruits was 2.6 times higher than that of leaves, while the carbohydrate content of leaves was five times higher than that of fruits.

The concentration of total phenols in fruitsgallic acid equivalent (GAE), (107.07 mg GAE $\left.100 \mathrm{~g}^{-1}\right)$ was lower than that found in leaves (132.46 mg GAE $100 \mathrm{~g}^{-1}$ ) [1], classifying the content of polyphenols in fruits into three categories: Low ( $<100 \mathrm{mg}$ GAE $\left.100 \mathrm{~g}^{-1}\right)$, moderate $\left(100-500 \mathrm{mg}\right.$ GAE $\left.100 \mathrm{~g}^{-1}\right)$, and high (>500 mg GAE $100 \mathrm{~g}^{-1}$ ). Other studies have used this classification [26]. According to this classification, both fruits and leaves presented moderate levels of polyphenols (Table 3).

The ascorbic acid content showed lower values in Garcinia gardneriana fruits $\left(25.23 \mathrm{mg} / 100 \mathrm{~g}^{-1}\right)$ in comparison with leaves $\left(30.26 \mathrm{mg} / 100 \mathrm{~g}^{-1}\right)$. Vitamin $C$ is an important natural nutrient in daily diet [27]. Fruits offer several health benefits and are part of a group of foods rich in bioactive compounds, mainly antioxidants [28]. The ascorbic acid reduces tocopherol radicals back to their active forms on cell membranes, providing anticancer potential [29].

The carotenoid contents were verified with smaller amounts in fruits $(27.05 \mathrm{mg}$ of $\beta$-carotene/100 $\mathrm{g}^{-1}$ ) of Garcinia gardneriana in relation to leaves $\left(76.25 \mathrm{mg}\right.$ of $\beta$-carotene/100 $\left.\mathrm{g}^{-1}\right)$. Carotenoids are present mainly in vegetables and fruits and are efficient in organic protection against carcinogenesis. 
In vitro and in vivo tests with carotenoids have played important roles in the treatment and prevention of cancer, demonstrating an effective antioxidant action [30].

The determination of the free radical scavenging activity by the DPPH (radical scavenging activity using DPPH (1,1-diphenyl-2-picrylhydrazyl) assay) method in extracts and fractions of G. gardneriana fruits and leaves showed that extracts and fractions of leaves showed better activities when compared with extracts and fractions of fruits, except for the hexane fraction (Table 4).

Table 4. Determination of antioxidant activity in vitro, $\mathrm{CI}_{50}(50 \%$ inhibition values)data $(\mu \mathrm{g} / \mathrm{mL})$, by the DPPH (radical scavenging activity using DPPH (1,1-diphenyl-2-picrylhydrazyl) assay) method for extracts and fractions of fruits (peel, pulp, and seed) and leaves of Garcinia gardneriana.

\begin{tabular}{lll}
\hline \multicolumn{1}{c}{ Extract and Fraction } & Fruit $(\mu \mathrm{g} / \mathrm{mL})$ & Leaf $(\mu \mathrm{g} / \mathrm{mL})$ \\
\hline Ethanol extract & $39.13 \pm 0.09^{\mathrm{a}}$ & $16.95 \pm 0.80^{\mathrm{b}}$ \\
Hexane fraction & $20.20 \pm 1.21^{\mathrm{a}}$ & $27.03 \pm 1.54^{\mathrm{b}}$ \\
Chloroform fraction & $103.37 \pm 3.32^{\mathrm{a}}$ & $14.27 \pm 1.36^{\mathrm{b}}$ \\
Ethyl acetate fraction & $73.40 \pm 10.72^{\mathrm{a}}$ & $16.68 \pm 0.63^{\mathrm{b}}$ \\
Hydromethanol fraction & $166.64 \pm 2.70^{\mathrm{a}}$ & $35.46 \pm 1.70^{\mathrm{b}}$ \\
\hline
\end{tabular}

Mean value \pm standard deviation, $\mathrm{n}=3$. Different letters indicate significant difference by Tukey test.

The chloroform fraction of the leaf showed a greater antioxidant activity, that is, a greater antioxidant action than DPPH (radical estável 2,2-difenil-1-picril hidrazil), with a value ofCI $\mathrm{I}_{50}$ $14.27 \mu \mathrm{g} / \mathrm{mL}$ (50\% inhibition values), as well as ethyl acetate and ethanol extract fractions with values $\mathrm{CI}_{50} 16.68 \mu \mathrm{g} / \mathrm{mL}$ and $16.95 \mu \mathrm{g} / \mathrm{mL}$, respectively. Studies carried out on the hydroalcoholic extract of bacupari leaves obtained $\mathrm{CI}_{50}$ of $34.83 \mu \mathrm{g} / \mathrm{mL}$. So far, no reports of whole fruits have been found, but only specific and isolated analyses such as skin, pulps, and seeds [31]. In fruits, the hexane extract showed the lowest $\mathrm{CI}_{50} 20.05 \mu \mathrm{g} / \mathrm{mL}$ compared to the other studied fractions. The antioxidant activity in other species of Garcinia and verified a $\mathrm{CI}_{50} 54 \mu \mathrm{g} / \mathrm{mL}$ for Garcinia humilis and $40.77 \mu \mathrm{g} / \mathrm{mL}$ for Garcinia xantochymus [26].

\subsection{Evaluation of the Antiproliferative Activity of Extracts and Fractions of Garcinia gardneriana Fruits and} Leaves in Cancer Cell Lines

The Figures 4 and 5 show values to $\mathrm{GI}_{50}$ (concentrations that inhibits ion $50 \%$ of cell proliferation) expressed as $\mu \mathrm{g} / \mathrm{mL}, \mathrm{GI}_{50}<250 \mu \mathrm{g} / \mathrm{mL}$, and Table 5 shows complete data. According to the National Cancer Institute (NCI), an extract that has a $\mathrm{GI}_{50}<30 \mu \mathrm{g} / \mathrm{mL}$ is considered active [32].

Among the results obtained by the EEF extracts analyzed at concentrations of $0.25,2.5,25$, and $250 \mu \mathrm{g} / \mathrm{mL}$ after $48 \mathrm{~h}$ of incubation (Figure 4), the EEF and EEFH and EEFC fractions were active in all lines, with $\mathrm{GI}_{50}$ ranging from $15.81 \mu \mathrm{g} / \mathrm{mL}$ to $27.10 \mu \mathrm{g} / \mathrm{mL}$. The EEFA and EEFW fractions were not active in any of the neoplastic lines tested $\left(\mathrm{GI}_{50}>250 \mu \mathrm{g} / \mathrm{mL}\right)$.

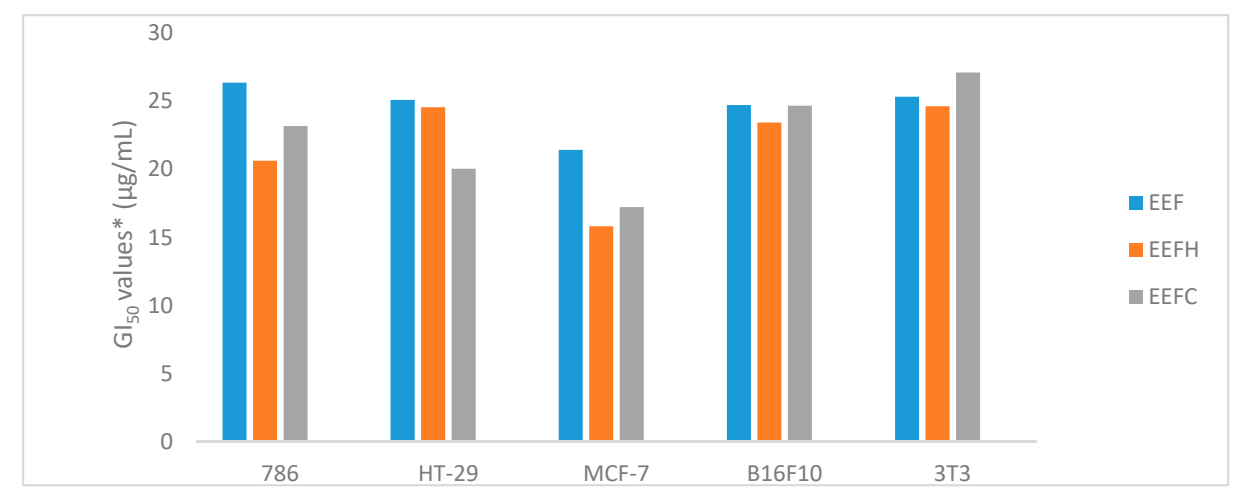

Figure 4. Cytotoxic activity, $\mathrm{GI}_{50}$ values $(\mu \mathrm{g} / \mathrm{mL})$ for extracts and fractions of fruits of Garcinia gardneriana, lines 786 (kidney carcinoma), HT-29 (colon carcinoma), MCF-7 (breast carcinoma), B16-F10 (murine melanoma), and NIH/3T3 (murine fibroblast). * Concentration that inhibits 50\% of cell growth determined 
by nonlinear regression analysis using the software ORIGIN 6.0. Mean value \pm standard deviation, $n=3$. EEF (fruit ethanolic extract), EEFH (hexane fraction), and EEFC (chloroform fraction).

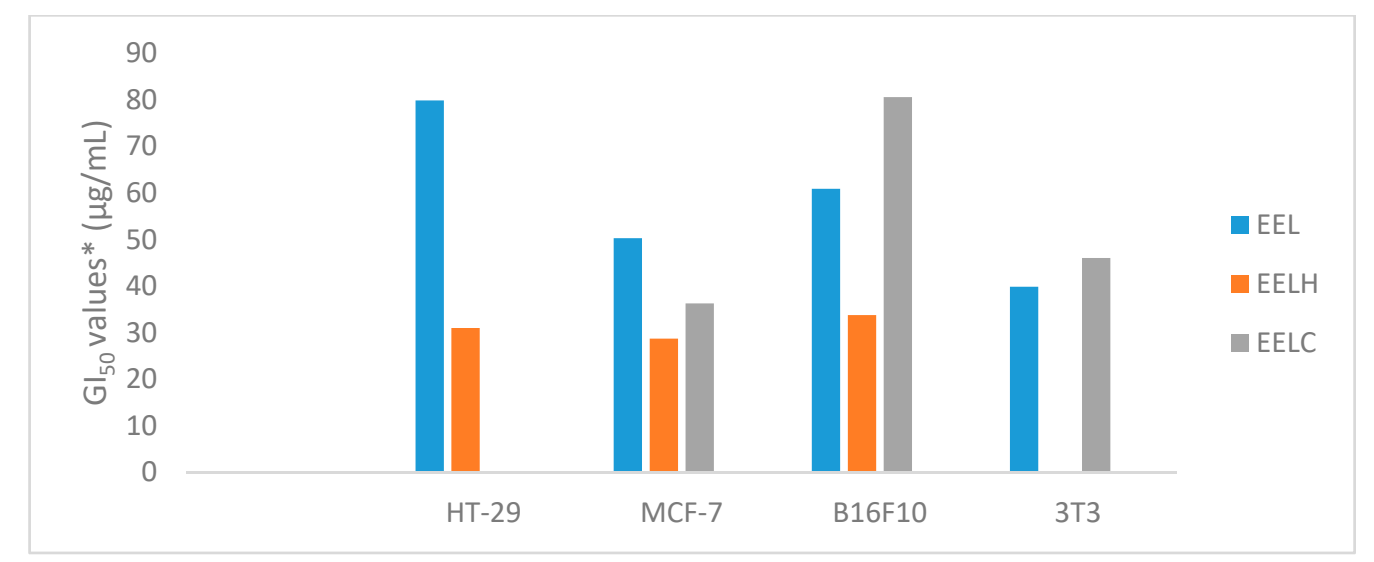

Figure 5. Cytotoxic activity, $\mathrm{GI}_{50}$ values* $(\mu \mathrm{g} / \mathrm{mL})$ for extracts and fractions of leaves of Garcinia gardneriana, HT-29 (colon carcinoma), MCF-7 (breast carcinoma), B16-F10 (murine melanoma), and NIH/3T3 (murine fibroblast). ${ }^{*}$ Concentration that inhibits $50 \%$ of cell growth determined by nonlinear regression analysis using the software ORIGIN 6.0. Mean value \pm standard deviation, $\mathrm{n}=3$. EEL (ethanol leaf extract), EELH (hexane fraction), and EELC (Chloroform fraction).

The EEL showed no cytotoxic activity in the lines tested $\left(\mathrm{GI}_{50}<30 \mu \mathrm{g} / \mathrm{mL}\right)$, except for the EELH fraction, which was active in the MCF-7 line $\left(\mathrm{GI}_{50}=28.7 \mu \mathrm{g} / \mathrm{mL}\right)$. The cytotoxic activity of EEF and EELC in the normal cell (NIH/3T3, murine fibroblast) was lower than that in the same extracts obtained from fruits. The EEFH was more cytotoxic $\left(\mathrm{GI}_{50}<24.63 \mu \mathrm{g} / \mathrm{mL}\right)$ in fruits than in leaves. The EELA and EELHM did not show this activity $\left(\mathrm{GI}_{50}>250 \mu \mathrm{g} / \mathrm{mL}\right)$.

Among the results obtained by the EEF and EEL extracts analyzed at concentrations of 0.25, 2.5, 25, and $250 \mu \mathrm{g} / \mathrm{mL}$ after $48 \mathrm{~h}$ of incubation (Table 5), EEF, EEFH, and EEFC were active against all cell lines, with GI $_{50}$ ranging from $15.81 \mu \mathrm{g} / \mathrm{mL}$ to $27.10 \mu \mathrm{g} / \mathrm{mL}$. The EEFA and EEFW fractions were not active in any of the cancer cell lines tested $\left(\mathrm{GI}_{50}>250 \mu \mathrm{g} / \mathrm{mL}\right)$. For leaves' extract and fractions, only the hexane fraction, EELH, showed active against MCF-7 cell line $\left(\mathrm{GI}_{50}=28.7 \mu \mathrm{g} / \mathrm{mL}\right)$. The cytotoxic activity of EEF and EELC in the 3T3 line was lower than in the same extracts obtained from fruits. The EEFH was more cytotoxic $\left(\mathrm{GI}_{50}<24.63 \mu \mathrm{g} / \mathrm{mL}\right)$ in fruits than in leaves. The EEFA, EEFHM, EELA, and EELHM did not show this activity $\left(\mathrm{GI}_{50}>250 \mu \mathrm{g} / \mathrm{mL}\right)$. 
Table 5. Cytotoxic activity, $\mathrm{GI}_{50}$ values* $(\mu \mathrm{g} / \mathrm{mL}$ ), for extracts and fractions of fruits and leaves of Garcinia gardneriana, lines 786 (kidney carcinoma), HT-29 (colon carcinoma), MCF-7 (breast carcinoma), B16-F10 (murine melanoma), and NIH/3T3 (murine fibroblast).

\begin{tabular}{cccccccccccc}
\hline \multirow{2}{*}{ Line } & \multicolumn{10}{c}{ Sample $^{* * *}$} \\
\cline { 2 - 12 } & EEF & EEFH & EEFC & EEFA & EEFHM & EEL & EELH & EELC & EELA & EELHM & Doxorubicin ** \\
\hline 786 & 26.36 & 20.63 & 23.17 & $>250$ & $>250$ & $>250$ & $>250$ & $>250$ & $>250$ & $>250$ & 0.026 \\
HT-29 & 25.09 & 24.55 & 20.04 & $>250$ & $>250$ & 79.89 & 31.00 & $>250$ & $>250$ & $>250$ & 0.24 \\
MCF-7 & 21.42 & 15.81 & 17.22 & $>250$ & $>250$ & 50.29 & 28.7 & 36.29 & $>250$ & $>250$ & 0.025 \\
B16F10 & 24.71 & 23.43 & 24.67 & $>250$ & $>250$ & 60.92 & 33.79 & 80.59 & $>250$ & $>250$ & 0.026 \\
3T3 & 25.32 & 24.63 & 27.10 & $>250$ & $>250$ & 39.87 & $>250$ & 46.03 & $>250$ & $>250$ & 0.36 \\
\hline
\end{tabular}

${ }^{*}$ Concentration that inhibits $50 \%$ of cell growth determined by nonlinear regression analysis using the software ORIGIN 6.0. ${ }^{* *}$ Doxorubicin: Positive control. ${ }^{* * *}$ EEF (fruit ethanolic extract), EEFH (hexane fraction), EEFC (chloroform fraction), EEFA (ethyl acetate fraction), EEFW (hydromethanolic fraction), EEL (ethanol leaf extract), EELH (hexane fraction), EELC (chloroform fraction), EELA (ethyl acetate fraction), and EELW (hydromethanolic fraction). 


\section{Discussion}

The chemical profile of the ethanol extracts and fractions from the fruits and leaves of G. gardneriana, obtained by HPLC-DAD-EM analysis, revealed the presence of a great variety of phenolic compounds, especially in leaves. The observed results, showing the presence in both fruits and leaves of flavonoids, biflavonoids, catechins, xanthones, and others, corroborate the importance of phenolic compounds as promising active components. For several of the compounds found in the extracts of fruits and leaves, studies have attributed the following bioactive potentials: Antioxidant [33-35], antiproliferative, and apoptotic [36,37].

Several studies carried out on plants used in traditional medicine, evidencing the presence of xanthones and flavonoids, have shown that these compounds contribute to antioxidant activities [38,39] and that catechins have antioxidant properties similar to vitamin $C$ (ascorbic acid) that help to inhibit the action of free radicals, protecting the organism from some diseases, such as cancer [40,41].

It has already been reported as one of the main component acids of Garcinia indica species [18], in addition to isomers of citric acid $\left(5,5^{\prime}\right)$ and glycosylated citric acid $\left(4,4^{\prime}, 4^{\prime \prime}\right)$, all reported for the first time in fruits of G. gardneriana.

Among the phenolic compounds, the presence of flavonoids and biflavonoids identified in this chemical study may be related to the antiproliferative activity of leaf and fruit extracts. These compounds are electron donors. In their chemical structure, they present several hydroxyls that have an antioxidant action because they react and inactivate superoxide anion, singlet oxygen, and peroxide radicals and stabilize free radicals through hydrogenation or complexation with oxidizing species. They also act by inhibiting the cell cycle and inducing apoptosis [42].

The results found in this study corroborate other studies that have suggested that the consumption of exotic fruits should be stimulated as they are sources of steroidal compounds, fatty acids, pigments, and phenolic compounds that have a potential biological activity, specifically an antimutagenic activity, which is closely related with antitumor action since every tumor begins after the mutation of a normal cell [43].

The literature review of some compounds identified in Garcinia gardneriana extracts and fractions (Table 6) revealed they have promising activities, such as analgesic, antibacterial, antioxidant, antiviral, anti-inflammatory, antimicrobial, antifungal, cytotoxic, anti-caries, anti-parasitic, trypanocide, antiproliferative, and anti-tumor activities. 
Table 6. Biological activities of compounds identified in the extracts of G. gardneriana leaves and fruits. Modes and their biological activities were already reported in the references cited for the species Garcinia.

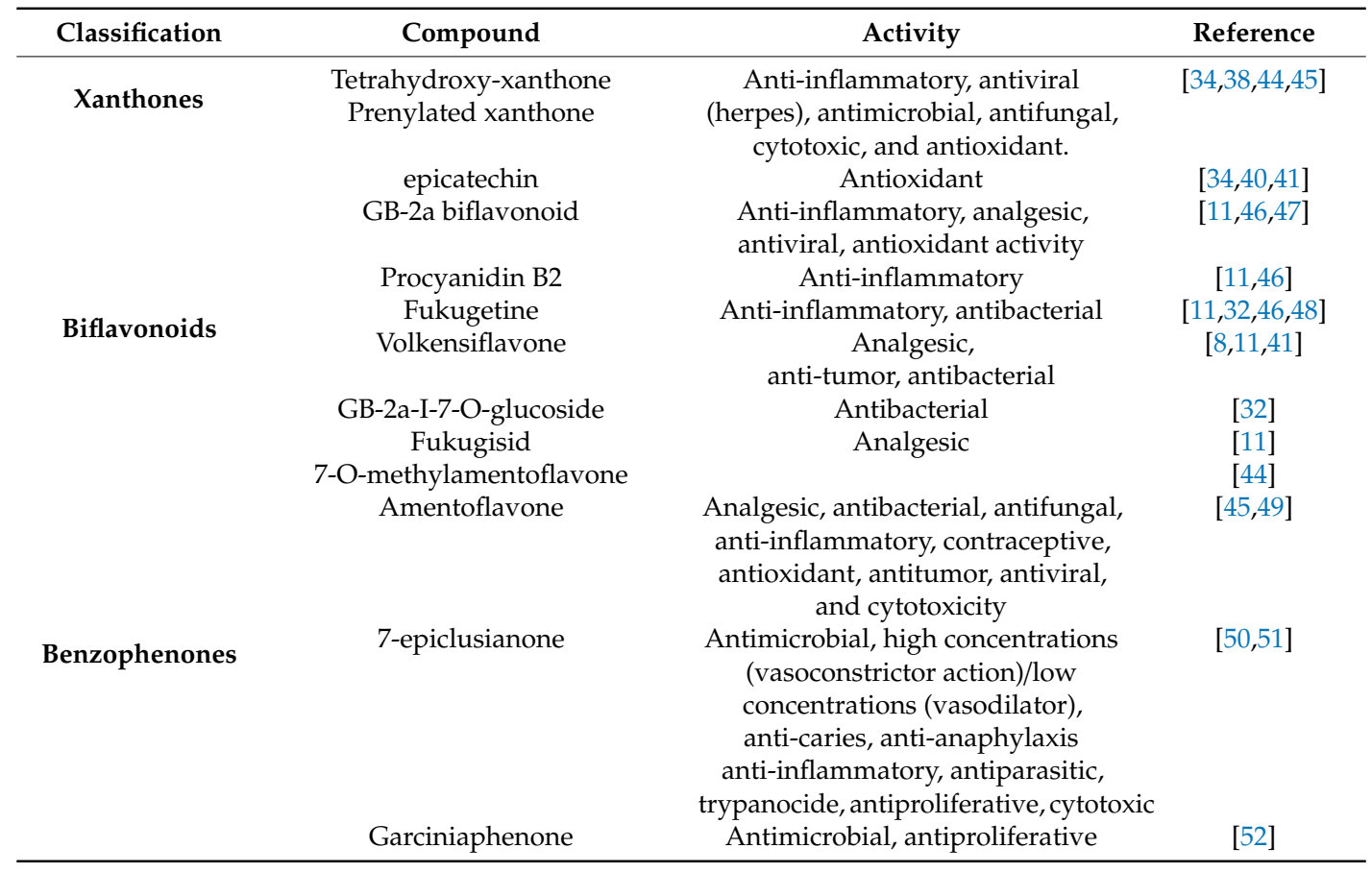

Cytotoxicity screening models provide important preliminary data to help to select plant extracts with potential antitumor properties for future bio-related studies [27]. The American National Cancer Institute guidelines assign a significant cytotoxicity effect to a promising anticancer product if the extracts have $\mathrm{GI}_{50}$ values lower than $30 \mu \mathrm{g} / \mathrm{mL}$ as well as small molecules, such as plant secondary metabolites, with a 30-50\% activity cutoff and activity concentrations ranging between 1 and $50 \mu \mathrm{M}$ (micromolar)with a potential as hit compounds [28,29].

The best $\mathrm{GI}_{50}$ value presented for fruits was against MCF-7 cell line ( $\left.\mathrm{GI}_{50} 15.81 \mu \mathrm{g} / \mathrm{mL}\right)$. To date, no reports have been found in the literature on the evaluation of the cytotoxicity of whole fruits (peel, pulp, and seed), as performed in this study. However, a cytotoxic study of the pericarp of Garcinia mongostana considering ethanolic extract and using the MTT (3-(4,5-dimethylthiazol, 2-yl)2,5-diphenyl-212 tetrazolium bromide) method was performed [16]. The results of the study showed an antiproliferative effect on cells of the MCF-7 human breast line ( $\mathrm{CI}_{50}$ of $\left.45 \mu \mathrm{g} / \mathrm{mL}\right)$. The MCF-7 line is sensitive to treatment and has an antiproliferative effect for an isolated benzophenone compound (7-epi-clusianone) from $\mathrm{G}$. brasiliense, presenting a $\mathrm{CI}_{50}$ value of $6 \mu \mathrm{g} / \mathrm{mL}$ [16].

According to the data shown in the manuscript of the 10 samples evaluated for cytotoxicity in the NHI/3T3 line (murine fibroblate) nontumoral cells, five of them were not cytotoxic because their $\mathrm{GI}_{50}$ values were greater than $250 \mu \mathrm{g} / \mathrm{mL}$. However, for the EEF, EFH, EFC, EEL, and EELC samples, the $\mathrm{GI}_{50}$ values were less than $50 \mu \mathrm{g} / \mathrm{mL}$, thus indicating cytotoxicity.

The aqueous extract of leaves of G. brasiliensis in the human cancer cell line MCF-7 showed that cell viability was affected only when it was used at concentrations above $1000 \mu \mathrm{g} / \mathrm{mL}$ with a $\mathrm{CI}_{50}$ of $312.0 \mu \mathrm{g} / \mathrm{mL} \pm 16.45 \mu \mathrm{g} / \mathrm{mL}$ [52].

In cytotoxicity tests carried out on leaves of G. gardneriana, the hydroalcoholic fraction $\left(\mathrm{GI}_{50} 16.97 \mu \mathrm{g} / \mathrm{mL}\right.$ ) was effective in the HL-60 line (human promyelocytic leukemia) [53,54]. In the HCT-8 line (colon, human cell line), a GI 50 of $15.30 \mu \mathrm{g} / \mathrm{mL}$ was reported in the ethanolic fraction and a $\mathrm{GI}_{50}$ of $11.68 \mu \mathrm{g} / \mathrm{mL}$ was reported in the hydroalcoholic fraction. The other extracts, such as hexane and acetate, had $\mathrm{GI}_{50}>30 \mu \mathrm{g} / \mathrm{mL}$. 
The presence of xanthones, benzophenones, and bioflavonoids causes an anticancer activity in several neoplastic lines even at low concentrations [54]. The xanthones already identified for the genus Garcinia have anti-inflammatory, antiviral (herpes), antimicrobial, antifungal, cytotoxic, and antioxidant activities, as reported [34,38,44,45]. Among them, epicatechin has antioxidant properties [34,40,41].

We can attribute the cytotoxic effects found in fruits and leaves to the presence of amentoflavones, as described in the literature, with analgesic, antibacterial, anti-inflammatory, antioxidant, and antitumor properties $[47,49]$.

Other compounds identified in the genus Garcinia are 7-epiclusianone, with antiphylactic, anti-inflammatory, antiparasitic, trypanocide, antiproliferative, and cytotoxic activity, [50,51] and Garcinia fenone, with antiproliferative and antimicrobial activity [53].

Fruits and leaves may vary in relation to bioactive compounds and physical chemical composition due to several factors such as location, vegetation, degree of ripeness, processing, storage, and climatic conditions [16].

The fruits of Garcinia gardneriana showed a high moisture content $(82.17 \%)$, as other species, such as Garcinia brasiliense $(80.3 \pm 1.70 \%)$. The moisture content of Garcinia humilis $(87.30 \pm 0.94 \%)$ and Garcinia xanthochymus $(89.04 \pm 0.13 \%)$ pointed out that several factors, such as season, climate, production period, and others, can influence the water content in fruits [11].

As for the protein content, the fruits presented 1.35 per $100 \mathrm{~g}^{-1}$, as expected for fruit pulps, corroborating with those who cited several native Cerrado fruits, such as araçá (Psidium cattleyanum)

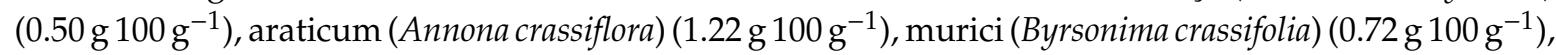

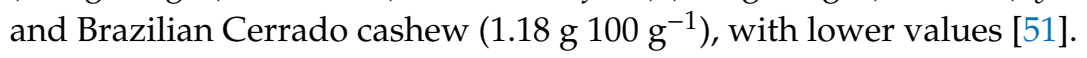

In the human body, phenolic compounds act by eliminating free radicals, promoting protection against oxidative stress, and generating additional health benefits. The quantification of the biological effects of phenolic compounds is important, as it becomes a way to evaluate the antioxidant properties of a plant species [52].

In this study, the value found on the leaf was greater than that described for the same species using the same methodology (28.06 and $9.22 \mathrm{mg} \mathrm{GAE} 100 \mathrm{~g}^{-1}$ ) for leaves and branches, respectively [55]. In leaves of $G$. atrovirids with average concentrations of $1.792 \mathrm{~g}$ gallic acid $100 \mathrm{~g}^{-1}, 34.39 \pm 0.48 \mathrm{~g}$ gallic acid $100 \mathrm{~g}^{-1}$ in aqueous extract of $G$. brasiliensis and $15.98 \pm 0.79 \mathrm{~g}$ gallic acid $100 \mathrm{~g}^{-1}$ in ethanol extract was found $[56,57]$.

On the other hand, higher values were found in studies carried out on the fruit pulp regarding the presence of phenolic compounds in G. humilis (373 mg GAE $100 \mathrm{~g}^{-1}$ ) and G. xantochymus (100.55 mg GAE $\left.100 \mathrm{~g}^{-1}\right)$ [11] and in fruits of G. pedunculata (189.8 mg $\left.\pm 65.0 \mathrm{GAE} 100 \mathrm{~g}^{-1}\right)$ and G. Morella (183.0 mg $\left.\pm 62.0 \mathrm{GAE} 100 \mathrm{~g}^{-1}\right)$ [17]. The leaf aqueous extract of Garcinia brasiliensis presented $343.98 \pm 4.8 \mathrm{mg} \mathrm{GA} / \mathrm{g}$ and Fukugiside as a major component and showed important antimicrobial and antioxidant properties, besides not having shown cytotoxic activity in human dermal fibroblasts, making its use a potential for the development of new drugs for cutaneous lesions' treatment [12].

Vitamin C is as an important natural nutrient in the daily diet [27]. Fruits offer several health benefits and are part of a group of foods rich in bioactive compounds, mainly antioxidants [28]. The ascorbic acid reduces tocopherol radicals to their active forms on cell membranes providing anticancer potential [29].

The ascorbic acid content of Garcinia gardneriana showed lower values for fruits $\left(25.23 \mathrm{mg}^{\left.100 \mathrm{~g}^{-1}\right)}\right.$ and higher for leaves (30.26 mg $100 \mathrm{~g}^{-1}$ ). However, they are considered higher when compared to other fruits of the same family and species: Bacuri (Garcinia gardneriana) (2.4 mg $\left.100 \mathrm{~g}^{-1}\right)$,

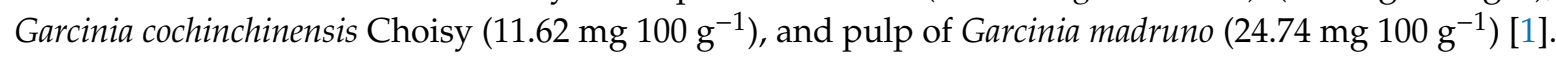

However, $40.32 \mathrm{mg} 100 \mathrm{~g}^{-1}$ in the pulp of Garcinia xanthochymus Hook was reported, which is higher than that found in the present study [26].

The recommended daily intake (RDI) of vitamin C, according to current Brazilian legislation ANVISA (National Health Surveillance Agency), RDC (Resolution of the Collegiate Board)- 269/05 is $45 \mathrm{mg}$ (recommendation for an adult). This corroborates studies that have shown that both the 
consumption of fruits and natural juices benefits the body for maintaining the balance of the antioxidant system and by improving plasma levels of vitamin $C$ among other compounds of this nature [58,59].

Carotenoids are present mainly in vegetables and fruits, being efficient in organic protection against carcinogenesis. In vitro and in vivo tests with carotenoids have played important roles in the treatment and prevention of cancer, demonstrating an effective antioxidant action [30].

The contents of carotenoids in the pulp of fruits of the species Garcinia brasiliensis was $191.8 \mathrm{mg}$ of $\beta$-carotene $100 \mathrm{~g}^{-1}$ [52]. However, it was reported that achachairu (Garcinia humilis Vahl) and yellow mangosteen (Garcinia xanthochymus Hook) had carotenoid contents of 61.4 and $134.82 \mathrm{mg}$ of $100 \mathrm{~g} \beta$-carotene ${ }^{-1}$, respectively. These values are higher than those found in the present study [60].

The fruit and the leaf can be considered as a rich source of carotenoids as they had a content greater than $20 \mu \mathrm{g} / \mathrm{g}^{-1}\left(2 \mathrm{mg} / 100 \mathrm{~g}^{-1}\right)$, which is the minimum value considered for a food to be a source of this compound [57].

As for the antioxidant activity of extracts, the chloroform fraction of leaves showed a greater activity, i.e., a greater antioxidant action than DPPH, with a $\mathrm{CI}_{50} 14.27 \mu \mathrm{g} / \mathrm{mL}$, as well as the ethyl acetate and ethanolic extract fractions, with $\mathrm{CI}_{50} 16.68 \mu \mathrm{g} / \mathrm{mL}$ and $16.95 \mu \mathrm{g} / \mathrm{mL}$, respectively. Studies carried out on the hydroalcoholic extract of bacupari leaves obtained a $\mathrm{CI}_{50}$ of $34.83 \mu \mathrm{g} / \mathrm{mL}$ [31].

So far, no reports on whole fruits have been found, but only specific and isolated analyses such as skin, pulps, and seeds. In fruits, the hexane extract showed the lowest $\mathrm{CI}_{50}(20.05 \mu \mathrm{g} / \mathrm{mL})$ compared to the other studied fractions. The antioxidant activity in other species of Garcinia was studiedand a $\mathrm{CI}_{50}$ $54 \mu \mathrm{g} / \mathrm{mL}$ for Garcinia humilis and $40.77 \mu \mathrm{g} / \mathrm{mL}$ for Garcinia xantochymus was verified [11].

Compared to the method of reducing capacity of the reagent Folin-Ciocalteau, the relations repeated: Leaves presented a higher phenolic concentration with a better result in relation to fruits. An important correlation between antioxidant activity and phenolic compounds has also been reported in other studies on fruits $[60,61]$.

Antitumor biological activity exerted by melon residues can be explained by the presence of phenolic content, such as flavonoids and tannins, and the high antioxidant capacity demonstrated by in vitro assays. We observed antiproliferative effects for melon residues' extracts on tumor cells that might have been caused by the activation of cell death mechanisms. Several antioxidant mechanisms of compounds present in melon peels and seeds might be associated with antiproliferative effects. Several enzymes, such as cytochrome $\mathrm{C}$ oxidase, ascorbate oxidase, and superoxide dismutase, are involved in cellular redox mechanisms [14].

Dietary antioxidants may be beneficial in preventing neoplasia due to their role in terms of immune response, since phagocytic cells produce free radicals as a defense of the body against the infection generated, and an adequate intake of these antioxidants is relevant to prevent damage caused by oxidant immune cells themselves [43].

Phenols', flavonoids', tannins', and alkaloids' contents were estimated much higher in polar fractions like fractionated ethyl acetate (TBEE), butanol (TBBE) and water (TBWE).

Thus, the presence of these important phytochemicals in the polar fractions might play an important role in establishing phytochemical content-function relationship, explaining their antioxidant and antiproliferative activity through various mechanisms like cell cycle arrest and apoptosis. Polar fractions of Terminalia belerica were seen to act as potent in vitro reactive oxygen and nitrogen species scavengers. Moreover butanol (TBBE) and water (TBWE) fractions were observed to be selectively cytotoxic towards breast cancer (MCF-7), cervical cancer (HeLa), and glioblastoma (U87) cell lines. These fractions arrested growth of MCF-7, HeLa, and U87 cells at G2/M phase, while ethyl acetate fraction (TBEE) caused apoptosis to check the growth of these cancer cells but none showed toxicity towards normal fibroblast cells (WI-38 cell line). These observations were further confirmed with imaging where arrested cells did not incorporate BrdUin DNA as compared to control cells. Moreover, butanol and water extracts of Terminaliabelerica upregulated p53 and p21 tumor suppressor proteins in MCF-7, $\mathrm{HeLa}$, and U87 cells, which corroborated with G2/M arrest and apoptosis. Hence, our findings suggest T. belerica polar fractions (TBEE, TBBE, TBWE) as potent antioxidant and anticancer extracts which 
can be selectively used as a remedy against various types of cancer, probably due to the presence of various bioactive compounds identified [62].

The antioxidants do not always promote cell proliferation. Several studies report that antioxidants contribute to the anticancer effect, as long as their concentrations are evaluated. Apoptosis is cell death mechanisms induced by the intracellular increase in the generation of free radicals, thus causing the inhibition of tumor growth. Higher antioxidants' concentrations decrease the generation of free radicals and cause inhibition of apoptosis. While normal concentrations of Glutathione (GSH) and other antioxidants in the intracellular space protect nuclear DNA from lesions caused by reactive oxygen species and decrease the prevalence of cancer. Normal amounts of Glutathione GSH and other antioxidants in the cancer already installed cause an increase in malignant cell proliferation and a decrease in apoptosis and facilitate the tumor neoangiogenesis $[40,63]$.

Human antioxidative defense system includes superoxide dismutase (SOD), catalase (CAT), glutathione peroxidase (GPx), glutathione (GSH), and others, and allows the elimination of excess reactive oxygen species (ROS) including, among others, superoxide anions $\left(\mathrm{O}_{2}{ }^{-} \bullet\right)$, hydroxyl radicals $(\mathrm{OH} \bullet)$, alkoxyl radicals $(\mathrm{RO} \bullet)$, and peroxyradicals $(\mathrm{ROO} \bullet)$. However, our endogenous antioxidant defense systems need exogenous antioxidants originating reducing compounds such as vitamin $C$, vitamin E, carotenoids, and polyphenols. There is continuous demand for exogenous antioxidants in order to prevent oxidative stress, representing a disequilibrium redox state in favor of oxidation [64].

Several studies show controversial results of exogenous antioxidants, discussing that the type, dosage, and matrix of exogenous antioxidants may be determining factors impacting the balance between beneficial or deleterious effects of these natural compounds. Double-edged effects of exogenous antioxidants on cellular responses include oxidative, nitrosative, and dicarbonyl metabolisms and other pathways such as inflammatory processes, depending potentially on their concentrations: Physiologic doses lead to beneficial effects, whereas high doses may result in harmful effects [64].

Different concentrations of antioxidants were reported to generate diverse biological effects, and higher or lower concentrations showed cytotoxicity in several cancer cell lines $[65,66]$. Other studies demonstrated a relationship between the antioxidant activity of extracts and, consequently, their anticancer activity in cancer cell lines, based on the calculated Pearson coefficient. Oftentimes, this correlation was not found between the anticancer and antioxidant activity [66,67].

Our results showed that the EEF and EEFH, with the values of $\mathrm{GI}_{50}$ lower than $30 \mu \mathrm{g} / \mathrm{mL}$, possess the best antioxidant properties ( $\mathrm{IC}_{50} 39.13 \mu \mathrm{g} / \mathrm{mL}$ and $20.20 \mu \mathrm{g} / \mathrm{mL}$ ). However, EEFC did not possess free radical scavenging properties and was also one of the most active anticancer agents.

Its antiproliferation activity could be related to different mechanisms of action. Our data cannot prove if the presence of polyphenols are responsible for this biologic activity, even though the value was considerate moderate $\left(100-500 \mathrm{mg} / 100 \mathrm{~g}^{-1}\right.$ of GAE). It was the same for the ascorbic acid. Content showed values $25.23 \mathrm{mg} / 100 \mathrm{~g} \mathrm{~g}^{-1}$ and $30.26 \mathrm{mg} / 100 \mathrm{~g}^{-1}$ in fruits and leaves. The vitamin $\mathrm{C}$ has antioxidant properties and protective action against breast cancer [68].

EEF and EEFH appear to be good sources of phytochemicals with antioxidant and potential anticancer activities. This study provides the initial evidence of the potential of these extracts as antiproliferative agents and their possible chemopreventive activity via their antioxidant properties.

\section{Materials and Methods}

\subsection{Plant Material and Samples' Preparation}

Garcinia gardneriana fruits and leaves were collected in Campo Grande, Brazil (geographical coordinates: Latitude -20.533720 and longitude -54.675146 ) and identified by a botanist from Campo Grande, Mato Grosso do Sul (Herbarium of the Universidade Federal de Mato Grosso do Sul, where a voucher, specimen no. 54611, is deposited).

The dried fruits $(354.84 \mathrm{~g}$ ) and leaves $(116.13 \mathrm{~g})$ of Garcinia gardneriana were powdered separately and extracted with ethanol by maceration for seven days. The resulting solutions were filtered and 
concentrated under reduced pressure at maximum temperature of $38^{\circ} \mathrm{C}$, yielding $316.38 \mathrm{~g}$ of ethanolic extract of fruits and $116.13 \mathrm{~g}$ of ethanolic extract of leaves.

Aliquots of dried ethanol extracts of fruits (EEF $25.08 \mathrm{~g}$ ) and leaves (EEL -042.00 g) were separately solubilized in $500 \mathrm{~mL}$ of methanol:water solution (9:1) and then fractionated by partition with hexane, chloroform, and ethyl acetate, resultin, in four fractions for each ethanolic extract: Hexane (EEFH $2.85 \mathrm{~g}$ and EELH $11.52 \mathrm{~g}$ ), chloroform (EEFC 0.34g and EELC $12.84 \mathrm{~g}$ ), ethyl acetate (EEFA $5.91 \mathrm{~g}$ and EELA $3.07 \mathrm{~g}$ ), and hydromethanol (EEFW 14.08 and EELW $11.25 \mathrm{~g}$ ). The eight fractions were concentrated under reduced pressure at $38{ }^{\circ} \mathrm{C}$ and kept under refrigeration with their respective extracts, totaling 10 samples.

\subsection{Chemical Profile of EEFH and EELH}

The extracts and fractions (EEF, EEFC, EEFA, EEFW, EEL, EELC, EELA, EELW, $5 \mathrm{mg} / \mathrm{mL}$ ) were analyzed using a high-performance liquid chromatography (Prominence UFLC, Shimadzu, Kyoto, Japan) coupled to a diode-array detector $(190-400 \mathrm{~nm})$ and a mass spectrometer with an electrospray ionization (ESI) source and the quadrupole-time-of-flight (QTOF) (MicrOTOF-Q III, Bruker Daltonics, Billerica, MA, USA) analyzers operating in negative ion modes. Nitrogen was used as gas of nebulization ( 4 bar), dry $\left(9.1 \mathrm{~L} / \mathrm{min}\right.$ at $\left.200^{\circ} \mathrm{C}\right)$ and collision. The capillary voltage was set at $3500 \mathrm{~V}$ and the scan range was $\mathrm{m} / \mathrm{z} 100-1300$. The analysis was performed on a C-18 column (Kinetex, $150 \mathrm{~mm} \times 2.1 \mathrm{~mm}$ id, $2.6 \mu \mathrm{m}$ ) with an oven temperature of $40^{\circ} \mathrm{C}$. The mobile phase was deionized water (A) and acetonitrile (B), both containing $0.1 \%$ formic acid $(v / v)$, under the following gradient profile: $0-2 \mathrm{~min} 3 \% \mathrm{~B}, 2-25 \mathrm{~min} 3-25 \% \mathrm{~B}$, and $25-40 \mathrm{~min} 25-80 \% \mathrm{~B}$. The flow rate was $0.3 \mathrm{~mL} / \mathrm{min}$ and the injection volume was $5 \mu \mathrm{L}$. The extracts were prepared at $1 \mathrm{mg} / \mathrm{mL}$ using acetonitrile and water $(85: 15, v / v)$ and filtered on a $0.22 \mu \mathrm{m} \times 3.0 \mathrm{~mm}$ PTFE (Polytetrafluoroethylene) membrane (Millex ${ }^{\circledR}$, Millipore, Sigma-Aldrich, St. Louis, MO, USA).

\subsection{Centesimal Composition of Fruits and Leaves of Garcinia gardneriana}

The analyses were performed in triplicate on fruits and leaves of bacupari. The following parameters were determined: Moisture (determined in an oven at $105^{\circ} \mathrm{C}$ until constant weight [30]) analyzed in a muffle furnace at $550^{\circ} \mathrm{C}$, lipids (determined by direct extraction with organic solvent in a Soxhlet apparatus), and proteins (determined by the classic micro-Kjeldahl method using a nitrogen into protein conversion factor of 5.75) [69]. The determination of carbohydrates (including fiber) was performed by theoretical calculation (difference) in the results of the triplicates according to the formula:

$$
\% \text { Carbohydrates }=100-(\% \text { moisture }+\% \text { proteins }+\% \text { lipids }+\% a s h) .
$$

\subsection{In Vitro Cytotoxicity Assay}

The 10 samples were tested against the following tumor cell lines from the American Type Culture Collection (ATCC, Manassas, VA, USA): Murine melanoma (B16-F10), human breast adenocarcinoma (MCF-7), kidney adenocarcinoma (786-0), and colon carcinoma (HT-29). All of them were donated by Prof. Dr. João Ernesto de Carvalho (Center for Chemical, Biological and Agricultural Studies-CPQBA-Unicamp, Brazil). They were also tested on murine fibroblast (NIH-3T3) cell line obtained from the Cell Bank of Rio de Janeiro (Rio de Janeiro, Brazil).

The B16-F10 and NIH-3T3 cells were grown in high-glucose DMEM (Dulbecco's modified GAE medium) and the other lines in RPMI-1640 (Roswell Park Memorial Institute Medium) (Sigma-Aldrich, St. Louis, MO, USA), both containing 10\% fetal bovine serum (Gibco, Thermo Fisher Scientific, Waltham, MA, USA), streptomycin $(100 \mu \mathrm{g} / \mathrm{mL})$, and penicillin $(100 \mathrm{U} / \mathrm{mL})$ (Sigma-Aldrich, St. Louis, MO, USA). The cells were subsequently distributed in 96 -well plates $(100 \mu \mathrm{L} /$ well $)$ and exposed for $48 \mathrm{~h}$ to increasing concentrations of extracts and their respective fractions $(0.25,2.5,25$, and $250 \mu \mathrm{g} / \mathrm{mL})$ $\left(\log _{10}\right.$ scale). Dilutions were prepared inDimethylsulfoxideDMSO $(0.1 \%)$. Cell proliferation was determined using the colorimetric method with sulforhodamine B (SRB) (Sigma, St. Louis, MO, USA). 
Using the concentration-response curve for cell lines, the $\mathrm{GI}_{50}$ (concentration causing $50 \%$ cell growth expressed in $\mu \mathrm{g} / \mathrm{mL}$ ) was determined by nonlinear regression analysis (sigmoidal fitting) using the software Origin 6.0 (OriginLab Corporation, Northampton, MA, USA) [12].

According to the National Cancer Institute (NCI), the extract with $\mathrm{GI}_{50}<30 \mu \mathrm{g} / \mathrm{mL}$ will be considered active [70]. In this study, $\mathrm{GI}_{50}$ values $<250 \mu \mathrm{g} / \mathrm{mL}$ were considered active and $\mathrm{GI}_{50}>250 \mu \mathrm{g} / \mathrm{mL}$ were inactive.

\subsection{Antioxidant Property}

\subsubsection{Determination of Total Phenols}

The quantification of phenolic compounds was performed using the Folin-Ciocalteau method. The ethanolic extracts were dissolved in methanol to obtain a concentration of $0.5 \mathrm{mg} / \mathrm{solids} / \mathrm{mL}^{-1}$ and then analyzed. The total amount of phenols in each extract was quantified using a standard curve prepared with gallic acid and expressed as gallic acid equivalent (GAE) [37].

\subsubsection{Evaluation of Antiradical Activity (DPPH)}

The method used to determine the antioxidant capacity in food extracts uses the reagent 2,2-difenil-1-picrilhidrazil (DPPH). The stable radical DPPH was used to assess the antiradical activity of natural antioxidants by assessing their ability to sequester free radicals. It was estimated according to the method adapted from Brand-Williams (1995) [18] using the microdilution technique in 96-well microplates. The radical scavenging activity was evaluated based on the $50 \%$ inhibition values $\left(\mathrm{IC}_{50}\right)$, which correspond to the amount of sample needed to inhibit the $50 \%$ DPPH oxidation. Data on the percentage of DPPH inhibition were obtained graphically from the absorbance values and $\log 10$ of the concentrations. The values were determined by linear regression $(Y=a+b x)$, such as "IC $\mathrm{C}_{50}=(50+\mathrm{b}) / \mathrm{a}$ ", subsequently adjusted to a power of 10 and expressed in $\mu \mathrm{g} / \mathrm{mL}$ of solution.

\subsubsection{Determination of Ascorbic Acid and Carotenoids}

The determination of ascorbic acid content was performed by titration with the reagent 2,6-dichlorophenolindophenol. The reading was taken in triplicate using a Libra Biochrom S60PC spectrophotometer at $450 \mathrm{~nm}$ and petroleum ether as blank. After the reading, the calculation of the carotenoid content was determined [18].

\subsection{Statistical Analyses}

All results were expressed as mean \pm standard error of the analyzed triplicate. The difference between groups was determined by one-way ANOVA (GraphPad Prism $5^{\circledR}$, San Diego, CA, USA). Values were considered significant when $p<0.05$.

\section{Conclusions}

Garcinia is a potential source of bioactive compounds with a significant antiproliferative effect in breast neoplastic lines (MCF), this being the second type of cancer with the highest incidence in women. In addition, the best antioxidant activity of Garcinia was found in the hexane fraction of fruits and in the chloroform fraction of leaves. Both fruits and leaves have a high vitamin $C$ content, exceeding by more than $50 \%$ the recommended daily intake (RDI). It can be consumed fruit or as juice and tea and other preparations, since $100 \mathrm{~g}$ of fruits contain $56.06 \%$ and leaves contain $67.24 \%$ of the recommended daily dose. Fruits have a lower protein and carbohydrate content than leaves, but a higher amount of lipids. Leaves indicate a high content of proteins, carbohydrates, and ashes $(7.64 \%, 54.79 \%$, and $4.93 \%$, respectively). Due to the high ash content found in leaves, it is relevant to evaluate the mineral profile. EEF and EEFH appear to be good sources of phytochemicals with antioxidant and potential anticancer activities. Further and more detailed studies should be carried out to understand the mechanism of antiproliferative activity against cancer cells lines. 
Author Contributions: Conceptualization, S.d.C.D., and D.B.; methodology, S.d.C.D., R.P.C., and D.B.; software, S.d.C.D. and D.B.; validation, S.d.C.D., M.C.B.L.eS., and D.B.; formal analysis, S.d.C.D., W.H.K.J., P.d.O.F., W.S.G., and D.B.; investigation, S.d.C.D. and D.B.; resources, S.d.C.D., C.A.F.A.; U.C.S., and D.B.; data curation, S.d.C.D. and D.B.; writing - original draft preparation, S.d.C.D., R.d.C.A.G., and D.B.; writing-review and editing, S.d.C.D., R.d.C.A.G., and D.B.; visualization, S.d.C.D., R.d.C.A.G., and D.B.; supervision, D.B.; project administration, S.d.C.D. and D.B.; funding acquisition, R.d.C.A.G. and D.B. All authors have read and agreed to the published version of the manuscript.

Funding: This research was funded by Federal University of Mato Grosso do Sul (UFMS) and Coordination of Superior Level Staff Improvement (CAPES) — Portaria 2016/2018. This study was financed in part by the CAPES-finance code 001.

Acknowledgments: We thank the Graduate Program in Biotechnology and Biodiversity and the Graduate Program in Health and Development in the Central-West Region of Brazil, Federal University of Mato Grosso do Sul-UFMS for support. The authors thank the Coordination for the Improvement of Higher Education Personal (Coordenação de Aperfeiçoamento de Pessoal de Nível Superior-CAPES).

Conflicts of Interest: The authors declare no conflict of interest.

\section{Abbreviation List:}

$\begin{array}{ll}\text { EEF } & \text { Fruit ethanolic extract } \\ \text { EEFA } & \text { Ethyl acetate fraction } \\ \text { EEFC } & \text { Chloroform fraction } \\ \text { EEFH } & \text { Hexane fraction } \\ \text { EEFW } & \text { Hydromethanolic fraction } \\ \text { EEL } & \text { Ethanol leaf extract } \\ \text { EELA } & \text { Ethyl acetate fraction } \\ \text { EELC } & \text { Chloroform fraction } \\ \text { EELH } & \text { Hexane fraction } \\ \text { EELW } & \text { Hydromethanolic fraction } \\ \text { MF } & \text { Molecular formula } \\ \text { MS/MS } & \text { Tandem mass spectrometry } \\ \text { Ppm } & \text { Parts per million } \\ \text { Rt } & \text { Retention time } \\ {[\mathrm{M}-\mathrm{H}]} & \text { Deprotonated ion } \\ \mathrm{m} / \mathrm{z} & \text { mass-to-charge ratio }\end{array}$

\section{References}

1. Rufino, M.D.S.M.; Alves, R.E.; De Brito, E.S.; Pérez-Jiménez, J.; Saura-Calixto, F.; Mancini-Filho, J. Bioactive compounds and antioxidant capacities of 18 non-traditional tropical fruits from Brazil. Food Chem. 2010, 121, 996-1002. [CrossRef]

2. Monache, F.; Mac-Quhae, M.; Monache, G.; Bettolo, G.; De Lima, R. Xanthones, xanthonolignoids and other constituents of the roots of vismia guaramirangae. Phytochemistry 1983, 22, 227-232. [CrossRef]

3. Monache, G.D.; Monache, F.D.; Waterman, P.G.; Crichton, E.G.; De Limas, R.A. Minor xanthones from Rheedia gardneriana. Phytochemistry 1984, 23, 1757-1759. [CrossRef]

4. Bennett, G.J.; Lee, H.H. Xantonas grom Guttiferae. Phytochemistry 1989, 4, 967-998. [CrossRef]

5. Hay, A.-E.; Aumond, M.-C.; Mallet, S.; Dumontet, V.; Litaudon, M.; Rondeau, D.; Richomme, P. Antioxidant Xanthones fromGarcinia vieillardii. J. Nat. Prod. 2004, 67, 707-709. [CrossRef]

6. Peres, V.; Nagem, T. Trioxygenated naturally occurring xanthones. Phytochemistry 1997, 44, $191-214$. [CrossRef]

7. Peres, V.; Nagem, T.J.; De Oliveira, F.F. Tetraoxygenated naturally occurring xanthones. Phytochemistry 2000, 55, 683-710. [CrossRef]

8. Botta, B.; Mac-Quhae, M.; Delle-Monache, F.; Delle-Monache, G.; De Mello, J.F. Chemical investigation of the genus Rheedia. V. biflavonoids and xanthochymol. J. Nat. Prod. 1984, 47, 1053-1064. [CrossRef]

9. Itoigawa, M.; Ito, C.; Tan, H.T.; Kuchide, M.; Tokuda, H.; Nishino, H.; Furukawa, H. Cancer chemopreventive agents, 4-phenylcoumarins from Calophyllum inophyllum. Cancer Lett. 2001, 169, 147-150. [CrossRef] 
10. Rao, A.; Sarma, M.; Venkataraman, K.; Yemul, S. A benzophenone and xanthone with unusual hydroxylation patterns from the heartwood of Garcinia pedunculata. Phytochemistry 1974, 13, 1241-1244. [CrossRef]

11. Luzzi, R.; Guimaraes, C.; Verdi, L.; Simionatto, E.; Monache, F.D.; Yunes, R.; Floriani, A.; Cechinel-Filho, V. Isolation of biflavonoids with analgesic activity from Rheedia gardneriana leaves. Phytomedicine 1997, 4, 141-144. [CrossRef]

12. Naves, V.M.L.; Santos, M.H.; Ribeiro, I.S.; Silva, C.A.; Silva, N.C.; Silva, M.A.; Silva, G.A.; Dias, A.L.T.; Ionta, M.; Dias, D.F. Antimicrobial and antioxidant activity of garciniabrasiliensis extracts. S. Afr. J. Bot. 2019, 124, 244-250. [CrossRef]

13. Green, K.; Brand, M.D.; Murphy, M.P. Prevention of mitochondrial oxidative damage as a therapeutic strategy in diabetes. Diabetes 2004, 53, S110-S118. [CrossRef] [PubMed]

14. Rolim, P.M.; Fidelis, G.P.; Padilha, C.E.A.; Santos, E.S.; Rocha, H.A.O.; Macedo, G.R. Phenolic profile and antioxidant activity from peels and seeds of melon (Cucumismelo L. var. reticulatus) and their antiproliferative effect in cancer cells. Braz. J. Med. Biol. Res. 2018, 51, 1-14. [CrossRef] [PubMed]

15. Mendonça, L.A.B.M.; Ferreira, R.D.S.; Guimarães, R.D.C.A.; Castro, A.; Franco, O.L.; Matias, R.; Carvalho, C.M.E. The Complex Puzzle of Interactions Among Functional Food, Gut Microbiota, and Colorectal Cancer. Front. Oncol. 2018, 8, 1-10. [CrossRef] [PubMed]

16. De Souza, V.R.; Pereira, P.A.P.; Queiroz, F.; Borges, S.V.; Carneiro, J.D.D.S. Determination of bioactive compounds, antioxidant activity and chemical composition of Cerrado Brazilian fruits. Food Chem. 2012, 134, 381-386. [CrossRef]

17. Neog, B.; Gogoi, N.; Gogoi, A.; Baruah, D.; Singh, K.D. Evaluation of antioxidant and hepatoprotective activity of fruit rind extract of Garcinia dulcis (Roxburgh) Kurz. Pharmacogn. Res. 2017, 9, 266-272. [CrossRef]

18. Brand-Williams, W.; Cuvelier, M.; Berset, C. Use of a free radical method to evaluate antioxidant activity. LWT 1995, 28, 25-30. [CrossRef]

19. Carrillo-Hormaza, L.; Ramírez, A.M.; Quintero-Ortiz, C.; Cossio, M.; Medina, S.; Ferreres, F.; Gil-Izquierdo, Á.; Osorio, E. Comprehensive characterization and antioxidant activities of the main biflavonoids of Garcinia madruno: A novel tropical species for developing functional products. J. Funct. Foods 2016, 27, 503-516. [CrossRef]

20. Auranwiwat, C.; Laphookhieo, S.; Rattanajak, R.; Kamchonwongpaisan, S.; Pyne, S.G.; Ritthiwigrom, T. Antimalarial polyoxygenated and prenylated xanthones from the leaves and branches of Garcinia mckeaniana. Tetrahedron 2016, 72, 6837-6842. [CrossRef]

21. Abderamane, B.; Tih, A.E.; Ghogomu, R.T.; Blond, A.; Bodo, B. New flavonoid C-O-C dimers and other chemical constituents from Garcinia brevipedicellata stem heartwood. Z. Nat. C 2016, 71, 233-241. [CrossRef] [PubMed]

22. Yao, H.; Chen, B.; Zhang, Y.; Ou, H.; Li, Y.; Li, S.; Shi, P.; Lin, X. Analysis of the Total Biflavonoids Extract from Selaginella doederleinii by HPLC-QTOF-MS and Its In Vitro and In Vivo Anticancer Effects. Molecules 2017, 22, 325. [CrossRef] [PubMed]

23. Stark, T.D.; Lösch, S.; Balemba, O.B.; Hofmann, T. Two new benzoyl glucuronosyl glycerols from the leaves of Garcinia buchananii Baker. Phytochem. Lett. 2017, 19, 187-190. [CrossRef]

24. Pandey, R.; Chandra, P.; Kumar, S.; Srivastva, M.; Aravind, A.A.; Shameer, P.; Rameshkumar, K. Simultaneous determination of multi-class bioactive constituents for quality assessment of Garcinia species using UHPLC-QqQ LIT -MS/MS. Ind. Crop. Prod. 2015, 77, 861-872. [CrossRef]

25. Na, Z.; Xu, Y. Chemical constituents from twigs of Garcinia xipshuanbannaensis. China J. Chin. Mater. Med. 2009, 34, 2338-2342.

26. Du, X.-G.; Wang, W.; Zhang, Q.-Y.; Cheng, J.; Avula, B.; Khan, I.A.; Guo, D. Identification of xanthones fromSwertia puniceausing high-performance liquid chromatography coupled with electrospray ionization tandem mass spectrometry. Rapid Commun. Mass Spectrom. 2012, 26, 2913-2923. [CrossRef]

27. Mariano, L.N.B.; Da Silva-Santos, J.E.; De Souza, P.; Boeing, T.; Somensi, L.B.; Bonomini, T.J.; Monache, F.D.; Filho, V.C.; Andrade, S.; Niero, R. Gastroprotective xanthones isolated from Garcinia achachairu: Study on mucosal defensive factors and $\mathrm{H}+, \mathrm{K}+-\mathrm{ATPase}$ activity. Chem. Interact. 2016, 258, 30-39. [CrossRef] [PubMed]

28. Li, P.; Senthilkumar, H.A.; Wu, S.-B.; Liu, B.; Guo, Z.; Fata, J.E.; Kennelly, E.J.; Long, C. Comparative UPLC-QTOF-MS-based metabolomics and bioactivities analyses of Garcinia oblongifolia. J. Chromatogr. B 2016, 1011, 179-195. [CrossRef] 
29. Dzoyem, J.P.; Lannang, A.M.; Fouotsa, H.; Mbazoa, C.D.; Nkengfack, A.E.; Sewald, N.; Jn, E. Anti-inflammatory activity of benzophenone and xanthone derivatives isolated from Garcinia (Clusiaceae) species. Phytochem. Lett. 2015, 14, 153-158. [CrossRef]

30. Wu, C.; Xu, H.; Héritier, J.; Andlauer, W. Determination of catechins and flavonol glycosides in Chinese tea varieties. Food Chem. 2012, 132, 144-149. [CrossRef]

31. Jaiswal, R.; Jayasinghe, L.; Kuhnert, N. Identification and characterization of proanthocyanidins of 16 members of the Rhododendron genus (Ericaceae) by tandem LC-MS. J. Mass Spectrom. 2012, 47, 502-515. [CrossRef]

32. Suffness, M.; Pezzuto, J.M. Assays related to cancer drug discovery. In Methods in Plant Biochemistry: Assays for Bioactivity; Hostettmann, K., Ed.; Academic Press: London, UK, 1990; Volume 6, pp. 71-133.

33. Yoshikawa, M.; Harada, E.; Miki, A.; Tsukamoto, K.; Liang, S.Q.; Yamahara, J.; Murakami, N. Antioxidant Constituents from the Fruit Hulls of Mangosteen (Garcinia mangostana L.) Originating in Vietnam. Yakugaku Zasshi 1994, 114, 129-133. [CrossRef]

34. Ferreres, F.; Silva, B.M.; Andrade, P.B.; Seabra, R.; Ferreira, M.A. Approach to the study of C-glycosyl flavones by ion trap HPLC-PAD-ESI/MS/MS: Application to seeds of quince (Cydonia oblonga). Phytochem. Anal. 2003, 14, 352-359. [CrossRef]

35. Li, Y.; Zhao, P.; Chen, Y.; Fu, Y.; Shi, K.; Liu, L.; Liu, H.; Xiong, M.; Liu, Q.-H.; Yang, G.; et al. Depsidone and xanthones from Garcinia xanthochymus with hypoglycemic activity and the mechanism of promoting glucose uptake in L6 myotubes. Bioorg. Med. Chem. 2017, 25, 6605-6613. [CrossRef] [PubMed]

36. Trisuwan, K.; Limtharakul, T. Benzophenone and xanthone derivatives from the inflorescences of Garcinia cowa. Arch. Pharmacal Res. 2012, 35, 1733-1738. [CrossRef] [PubMed]

37. Santa-Cecília, F.V.; Santos, G.B.; Fuzissaki, C.N.; Derogis, P.; Freitas, L.A.; Gontijo, V.S.; Stringheta, P.C.; Nagem, T.J.; Brigagão, M.R.; Dos Santos, M.H. 7-epiclusianone, the natural prenylated benzophenone, inhibits superoxide anions in the neutrophil respiratory burst. J. Med. Food 2012, 15, 200-205. [CrossRef]

38. Derogis, P.; Martins, F.T.; De Souza, T.C.; Moreira, M.E.D.C.; Filho, J.D.S.; Doriguetto, A.C.; Souza, K.R.D.; Veloso, M.P.; Dos Santos, M.H. Complete assignment of the1H and13C NMR spectra of garciniaphenone and keto-enol equilibrium statements for prenylated benzophenones. Magn. Reson. Chem. 2008, 46, 278-282. [CrossRef]

39. Mahamodo, S.; Rivière, C.; Christel, N.; Abedini, A.; Ranarivelo, H.; Duhal, N.; Roumy, V.; Hennebelle, T.; Sahpaz, S.; Lemoine, A.; et al. Antimicrobial prenylated benzoylphloroglucinol derivatives and xanthones from the leaves of Garcinia goudotiana. Phytochemistry 2014, 102, 162-168. [CrossRef]

40. Verdi, L.G.; Pizzolatti, M.G.; Montanher, A.B.; Brighente, I.M.; Smânia Júnior, A.; Smânia-Ed Ede, F.; Simionatto, E.L.; Monache, F.D. Antibacterial and brine shrimp lethality tests of biflavonoids and derivatives of Rheedia gardneriana. Fitoterapia 2004, 75, 360-363. [CrossRef]

41. Demarque, D.P.; Crotti, A.E.M.; Vessecchi, R.; Lopes, J.L.; Falcon, T. Fragmentation reactions using electrospray ionization mass spectrometry: An important tool for the structural elucidation and characterization of synthetic and natural products. Nat. Prod. Rep. 2016, 33, 432-455. [CrossRef]

42. Virgolin, L.B.; Seixas, F.R.F.; Janzantti, N.S. Composition, content of bioactive compounds, and antioxidant activity of fruit pulps from the Brazilian Amazon biome. Pesqui. Agropecu. Brasileira 2017, 52, 933-941. [CrossRef]

43. Kim, D.; Lee, K.W.; Lee, H.J.; Lee, C.Y. Vitamin C Equivalent Antioxidant Capacity (VCEAC) of Phenolic Phytochemicals. J. Agric. Food Chem. 2002, 50, 3713-3717. [CrossRef]

44. Liu, R.H. Health-Promoting Components of Fruits and Vegetables in the Diet12. Adv. Nutr. 2013, 4, 384S-392S. [CrossRef] [PubMed]

45. Klimczak, I.; Małecka, M.; Szlachta, M.; Gliszczyńska-Świgło, A. Effect of storage on the content of polyphenols, vitamin $C$ and the antioxidant activity of orange juices. J. Food Compos. Anal. 2007, 20, 313-322. [CrossRef]

46. Gomes, F.S. Carotenoids: A Possible protection against cancer development. Rev. Nutr. 2007, 5, 537-548. [CrossRef]

47. Yu, L.; Zhao, M.; Yang, B.; Zhao, Q.; Jiang, Y. Phenolics from hull of Garcinia mangostana fruit and their antioxidant activities. Food Chem. 2007, 104, 176-181. [CrossRef] 
48. Jantan, I.; Saputri, F.C. Benzophenones and xanthones from Garcinia cantleyana var. cantleyana and their inhibitory activities on human low-density lipoprotein oxidation and platelet aggregation. Phytochemistry 2012, 80, 58-63. [CrossRef] [PubMed]

49. Okoko, T. In vitro antioxidant and free radical scavenging activities of Garcinia kola seeds. Food Chem. Toxicol. 2009, 47, 2620-2623. [CrossRef] [PubMed]

50. Mackeen, M.; Ali, A.; Lajis, N.; Kawazu, K.; Hassan, Z.; Amran, M.; Habsah, M.; Mooi, L.; Mohamed, S. Antimicrobial, antioxidant, antitumour-promoting and cytotoxic activities of different plant part extracts of Garcinia atroviridis Griff. ex T. Anders. J. Ethnopharmacol. 2000, 72, 395-402. [CrossRef]

51. Gao, X.-M.; Yu, T.; Cui, M.-Z.; Pu, J.-X.; Du, X.; Han, Q.-B.; Hu, Q.-F.; Liu, T.-C.; Luo, K.Q.; Xu, H. Identification and evaluation of apoptotic compounds from Garcinia oligantha. Bioorganic Med. Chem. Lett. 2012, 22, 2350-2353. [CrossRef] [PubMed]

52. Kim, J.-K.; Park, R.; Kim, M.-S.; Kwon, D.-Y. Anti-adipogenic effects of Garcinia extract on the lipid droplet accumulation and the expression of transcription factor. BioFactors 2004, 22, 193-196. [CrossRef]

53. Lin, K.-W.; Huang, A.-M.; Yang, S.-C.; Weng, J.-R.; Hour, T.-C.; Pu, Y.-S.; Lin, C.-N. Cytotoxic and antioxidant constituents from Garcinia subelliptica. Food Chem. 2012, 135, 851-859. [CrossRef] [PubMed]

54. Zeraik, M.L.; Serteyn, D.; Deby-Dupont, G.; Wauters, J.-N.; Tits, M.; Yariwake, J.; Angenot, L.; Franck, T. Evaluation of the antioxidant activity of passion fruit (Passiflora edulis and Passiflora alata) extracts on stimulated neutrophils and myeloperoxidase activity assays. Food Chem. 2011, 128, 259-265. [CrossRef]

55. Uesato, S.; Kitagawa, Y.; Kamishimoto, M.; Kumagai, A.; Hori, H.; Nagasawa, H. Inhibition of green tea catechins against the growth of cancerous human colon and hepatic epithelial cells. Cancer Lett. 2001, 170, 41-44. [CrossRef]

56. Nagao, T.; Hase, T.; Tokimitsu, I. A Green Tea Extract High in Catechins Reduces Body Fat and Cardiovascular Risks in Humans. Obesity 2007, 15, 1473-1483. [CrossRef]

57. Moongkarndi, P.; Kosem, N.; Kaslungka, S.; Luanratana, O.; Pongpan, N.; Neungton, N. Antiproliferation, antioxidation and induction of apoptosis Bygarcinia mangostana (Mangosteen) on SKBR3 human breast cancer cell line. J. Ethnopharmacol. 2004, 90, 161-166. [CrossRef]

58. Cano-Campos, M.; Díaz-Camacho, S.; Uribe-Beltrán, M.; López-Angulo, G.; Montes-Avila, J.; Paredes-López, O.; Delgado-Vargas, F. Bio-guided fractionation of the antimutagenic activity of methanolic extract from the fruit of Randia echinocarpa (Sessé et Mociño) against 1-nitropyrene. Food Res. Int. 2011. [CrossRef]

59. Parveen, N.; Singh, M.P.; Khan, N.U.; Logani, M.K. Flavonoid constituents of Garcinia xanthochymus leaves. Phytother. Milano 1994, 65, 89-90.

60. Jung, H.-A.; Su, B.-N.; Keller, W.J.; Mehta, R.G.; Kinghorn, A.D. Antioxidant Xanthones from the Pericarp of Garcinia mangostana(Mangosteen). J. Agric. Food Chem. 2006, 54, 2077-2082. [CrossRef]

61. Mohamed, G.A.; Al-Abd, A.M.; El-Halawany, A.M.; Abdallah, H.M.; Ibrahim, S.R.M. New xanthones and cytotoxic constituents from Garcinia mangostana fruit hulls against human hepatocellular, breast, and colorectal cancer cell lines. J. Ethnopharmacol. 2017, 198, 302-312. [CrossRef] [PubMed]

62. Castardo, J.C.; Prudente, A.; Ferreira, J.; Guimarães, C.L.; Monache, F.D.; Filho, V.C.; Otuki, M.F.; Cabrini, D.A. Anti-inflammatory effects of hydroalcoholic extract and two biflavonoids from Garcinia gardneriana leaves in mouse paw oedema. J. Ethnopharmacol. 2008, 118, 405-411. [CrossRef] [PubMed]

63. Chen, Y.; Zhong, F.; He, H.-W.; Hu, Y.; Zhu, D.; Yang, G. Structure elucidation and NMR spectral assignment of five new xanthones from the bark of Garcinia xanthochymus. Magn. Reson. Chem. 2008, 46, 1180-1184. [CrossRef] [PubMed]

64. Abe, F.; Nagafuji, S.; Okabe, H.; Akahane, H.; Estrada-Muniz, E.; Huerta-Reyes, M.; Reyes-Chilpa, R. Trypanocidal constituents in plants 3 Leaves of Garcinia intermedia and heartwood of Calophyllum brasiliense. Biol. Pharm. Bull. 2004, 27, 141-143. [CrossRef]

65. Kaikabo, A.A.; Samuel, B.B.; Eloff, J.N. Isolation and activity of two antibacterial bioflavonoids from leaf extracts of Garcinia livingstonei (Clusiaceae). Nat. Prod. Commun. 2009, 10, 1363-1366.

66. Alves, T.M.; Alves, R.; Romanha, A.J.; Zani, C.L.; Santos, M.H.; Nagem, T.J. Biologicalactivitiesof 7-Epiclusianone. J. Nat. Prod. 1999, 62, 369-371. [CrossRef] [PubMed]

67. Branco-De-Almeida, L.; Murata, R.M.; Franco, E.M.; Dos Santos, M.H.; Alencar, S.M.; Koo, H.; Rosalen, P.L. Effects of 7-epiclusianone on Streptococcus mutans and caries development in rats. Planta Med. 2010, 77, 40-45. [CrossRef] 
68. Cruz, A.; Lemos, V.S.; Dos Santos, M.; Nagem, T.; Cortes, S. Vascular effects of 7-epiclusianone, a prenylated benzophenone from Rheedia gardneriana, on the rat aorta. Phytomedicine 2006, 13, 442-445. [CrossRef]

69. Neves, J.; Coelho, L.; Cordeiro, R.; Veloso, M.E.; Silva, P.; Dos Santos, M.; Martins, M.A. Antianaphylactic Properties of 7-Epiclusianone, a Tetraprenylated Benzophenone Isolated from Garcinia brasiliensis. Planta Med. 2007, 73, 644-649. [CrossRef]

70. Murata, R.M.; Branco-De-Almeida, L.; Yatsuda, R.; Dos Santos, M.H.; Nagem, T.J.; Rosalen, P.L.; Koo, H. Inhibitory effects of 7-epiclusianone on glucan synthesis, acidogenicity and biofilm formation by Streptococcus mutans. FEMS Microbiol. Lett. 2008, 282, 174-181. [CrossRef]

Sample Availability: The samples used are available from the authors.

(C) 2020 by the authors. Licensee MDPI, Basel, Switzerland. This article is an open access article distributed under the terms and conditions of the Creative Commons Attribution (CC BY) license (http://creativecommons.org/licenses/by/4.0/). 